\title{
From egg to adult: a developmental table of the ant Monomorium pharaonis
}

\author{
Luigi Pontieri $^{1 \dagger}$, Arjuna Rajakumar ${ }^{2 \dagger}$, Ab Matteen Rafiqi ${ }^{2,3}$, Rasmus Stenbak Larsen ${ }^{1}$, \\ Ehab Abouheif ${ }^{2}$, Guojie Zhang ${ }^{1,4^{*}}$
}

${ }^{1}$ Section for Ecology and Evolution, Department of Biology, University of Copenhagen, Universitetsparken 15, building 3, 2100 Copenhagen, Denmark.

${ }^{2}$ Department of Biology, McGill University, 1205 Avenue Docteur Penfield, Montréal, QC, Canada H3A 1B1.

${ }^{3}$ Beykoz Institute of Life Science and Biotechnology, Bezmialem Vakif University, Beykoz, 34820 Istanbul, Turkey.

${ }^{4}$ State Key Laboratory of Genetic Resources and Evolution, Kunming Institute of Zoology, Chinese Academy of Sciences, Kunming, 650223, China

${ }^{\dagger}$ Authors contributed equally to this work

*Corresponding Author: Guojie Zhang (guojie.zhang@bio.ku.dk) 


\begin{abstract}
(max 248 words)
Ants exhibit remarkable phenotypic diversity and, with over approximately 16,000 species across 6 continents, represent one of the most evolutionarily and ecologically successful groups of animals. All ants are eusocial with a reproductive division of labor between morphologically and/or behaviourally distinct castes within a single species. This has made ants an ideal system to study core questions of eco-evo-devo (ecological evolutionary developmental biology) by highlighting the role of developmental plasticity, epigenetics, ancestral developmental potentials, modularity, and major evolutionary transitions in the evolutionary process. Yet, despite their importance for ecoevo-devo, no complete ontological series for an ant has been published to date. We therefore present the first developmental table in ants, from egg to adult, for the Myrmicine ant Monomorium pharaonis. We identified and characterized 17 embryonic stages, 3 larval instars, and prepupal/pupal development. We found that the majority of landmarks identified during embryogenesis in the fruitfly Drosophila melanogaster are conserved in M. pharaonis. Furthermore, we can morphologically discriminate reproductive larvae (queen and male-destined larvae) from one another after the $1^{\text {st }}$ larval instar. Finally, this ontological series of M. pharaonis will serve as a blueprint for the generation of future ant developmental tables, which is key to understanding how the remarkable diversity in ants evolved.
\end{abstract}

Keywords. ants, Monomorium pharaonis, holometabolous insect, evo-devo, eco-evo-devo, embryo, larvae, pupa.

\title{
Introduction
}

A major goal of the field of evolutionary developmental biology (evo-devo) is to understand how developmental systems evolve and generate variation that facilitates or constrains evolution (Arthur 2002, Caroll 2008, Wagner 2014, Moczek et al. 2015). Over the last four decades, evo-devo has shown that the diversity in animal bodyplans involves tinkering with a relatively small number of highly conserved developmental regulatory genes, known as the 'genetic toolkit' (Patel et al. 1994, Quiring et al. 1994, Caroll 1995, Akam 1998, Hall 2003). Evo-devo studies on ants have played a crucial role in revealing the ecological dimensions of evo-devo, known as an emerging synthesis called 'eco-evo-devo'. This emerging field explores how interactions between the genetic toolkit and environmental factors, such as social regulation, nutrition, and temperature, can generate the phenotypic variation necessary to fuel evolutionary change (West-Eberhard 2003, Abouheif et al. 2014, Gilbert et al. 2015, Santos et al. 2015, Sommer and Mayer 2015, Toth and Rehan 2017, Rajakumar and Sanger 2018, Kapheim et al. 2020).

All ants are eusocial and have evolved a striking degree of phenotypic diversity across species. At the core of this diversity is a polyphenism within colonies, where a single multi-potent embryo can generate at least two discrete female phenotypes, namely a queen or a worker caste, in response to environmental cues (Brian 1974, Passera and Suzzoni 1979, Hölldobler and Wilson 1990, Hölldobler and Wilson 2009, Penick et al. 2012, ). Queen and worker castes display dramatic differences in morphology and life history, the key features being wing polyphenism, comprising of winged queens and wingless workers; a morphological and reproductive asymmetry between queen and worker castes; and within the worker caste, the evolution of soldiers. Each of these innovations evolved through the differential regulation of the genetic toolkit among castes during preimaginal stages of development (Dewitz 1878, Wheeler and Nijhout 1981, Wheeler 1986, Abouheif and Wray 2002, Wheeler 2003, Sameshima et al. 2004, Gotoh et al. 2005, Khila and Abouheif 2008, Khila and Abouheif 2010, Rajakumar et al. 2012, Gotoh et al. 2016, Béhague et al. 2018, Rajakumar et al. 2018, Oettler et al. 2019). Furthermore, within ant societies developing larvae play 
fundamental roles in colony-level regulation. For example, larvae have functional roles in social regulation across ant lineages in food processing, pheromone production and caste-ratio regulation (Mamsch 1967, Villalta et al. 2015, Ebie et al. 2015, Warner et al. 2016, Schultner et al. 2017, Warner et al. 2019).

To date, eco-evo-devo studies on ants have helped us to understand queen-worker caste differentiation (Gotoh et al. 2005, Khila and Abouheif 2008, Khila and Abouheif 2010, Penick et al. 2012, Qui et al. 2018, Chandra et al. 2018, Warner et al. 2019, Nagel et al. 2020), epigenetic regulation (Alvarado et al. 2015, LeBoeuf et al. 2016, Simola et al. 2016), worker polymorphism (Wheeler and Nijhout 1981, Abouheif and Wray 2002, Klein et al. 2018), social behaviour (Trible et al. 2017, Yan et al. 2017), modularity (Yang and Abouheif 2011, Londe et al. 2015), evolutionary novelty (Favé et al. 2015, Rajakumar et al. 2018, Powell et al. 2020), gene by environment interactions (Linksvayer et al. 2012, Schrader et al 2014, Singh and Linksvayer 2020), ancestral developmental potentials (Rajakumar et al. 2012), and major evolutionary transitions in individuality (Bernadou et al. 2018, Rafiqi et al. 2020). Despite the success of these recent eco-evodevo studies in ants, the absence of precise characterization of development hampers our ability to push forward functional characterization of the gene networks that may underlie key lineage specific innovations, such as the molecular and developmental mechanisms regulating queenworker caste determination. For example, the ability to establish transgenic lines with CRISPRCAS9 gene editing in any organism is predicated on a working knowledge of the timing and stages of that organism's development. This is evident in recent studies that have functionally manipulated gene expression during development within different ant lineages, where a detailed understanding of developmental timing was necessary to ensure the specificity and efficacy of reagents to downregulate gene expression (Alvarado et al. 2015, Trible et al. 2017, Yan et al. 2017, Rajakumar et al. 2018, Rafiqi et al 2020).

The lack of a complete developmental table of any ant species is surprising given the long and rich history of the study of ant development. Prior to the rise of population genetics and publication of Hamilton's seminal papers (Hamilton 1964, Hamilton 1972), there was a group of myrmecologists that pioneered eco-evo-devo studies in ants, which includes W.M. Wheeler (Wheeler 1893, Wheeler 1910, Wheeler 1911), Goestch (Metzl et al. 2018), Bier (Bier 1952), and Dewitz (Dewitz 1878), who were interested in developmental basis of caste determination, and Tanquary (Tanquary 1912), Blochmann (Blochmann 1892), Hegner (Hegner 1915), Lilienstern (Lilienstern 1932), and Buchner (Buncher 1918, Buchner 1965), who were interested in the development of endosymbionts within ant ovarioles and embryos. The first ontological series of ant embryonic development we are aware of was provided by Ganin, who described the embryos of Formica fusca from syncytial blastoderm through segmentation in 1869 (Ganin 1869). Work by Blochmann, Tanquerney, Hegner, and Buncher would add the embryonic descriptions for another Formicine genus Camponotus (Blochmann 1892, Tanquary 1912, Hegner 1915, Buncher 1918, Buchner 1965). W.M. Wheeler in 1918 and 1922 (Wheeler 1918, Wheeler 1922) described the general morphology of ant larvae and later George Wheeler and Jeanette Wheeler, who in a long series of publications between 1953 and 1990 extensively described the general morphology of larvae of approximately 800 species of ants (Wheeler and Wheeler 1953, Wheeler and Wheeler 1955, Wheeler and Wheeler 1976, Wheeler and Wheeler 1990). Only more recently are researchers beginning to describe in detail the number of instars in a given ant species (Sameshima et al. 2004, Fox et al. 2017, Fox et al. 2012, Masuko 2017, Solis et al. 2010; Alvarado et al. 2015, Rajakumar et al. 2018). 
Here we characterize a complete ontological series of the ant Monomorium pharaonis, spanning embryo, larval, and pupal stages. M. pharaonis is an invasive species in North America that is polygynous (multiple queens) and monoandrous (single mating), with a monomorphic worker caste. M. pharaonis is a promising model within social insects for functional analysis of developmental processes because queens and males (reproductives) practice within nest mating (intranidal), which allows the establishment and maintenance of colony lineages, or genetic lines, for several generations in laboratory conditions. Moreover, the worker caste is obligatory sterile, which ensures that all the brood is queen-produced. Furthermore, reproductives can be mated with unrelated partners, allowing the establishment of genetically heterogeneous crossed lines to investigate various aspects of ant colony organization and development-including the sociogenomic basis of social insect castes (Pontieri et al. 2017, Qui et al. 2018 Walsh et al. 2018, Warner et al. 2019, Walsh et al. 2020, Singh and Linksvayer 2020, Nagel et al. 2020), colony-level traits such as collective behaviors (Gordon 2019, Walsh et al. 2020), and caste/sex ratio ( Warner et al. 2016, Pontieri et al. 2017, Warner et al. 2018, Singh and Linksvayer 2020). Recently, a high-quality chromosome level reference genome of $M$. pharonis was released, which will facilitate investigation of the functions of genes and regulatory elements (Gao et al., in review). Finally, unlike many laboratory ant species, the production of reproductive castes can be initiated at any time by removing the queens (Edwards 1987), and the relatively short developmental time (approximately 45 days) allows for a quick availability of new reproductives for relatively rapid establishment of genetic lines. Below we show that M. pharaonis shares many conserved developmental features with other holometabolous insects, making it a good blueprint that will facilitate the generation of future ant developmental tables.

\section{Materials and Methods}

Ant colony maintenance and collection of eggs, larvae and pre-pupae. One $M$. pharaonis colony was used to collect egg, larval, pre-pupal and pupal stages. This colony was part of a larger stock of colonies artificially created in 2010 through the sequential cross of eight inbred lineages (see Schmidt et al. 2011 and Pontieri et al. 2017 for breeding methods) and has since been maintained at the University of Copenhagen. The colony was kept at $27 \pm 1{ }^{\circ} \mathrm{C}$ and $50 \% \mathrm{RH}$ in a plastic box $(27 \times$ $17 \times 9.5 \mathrm{~cm}$ ) coated with Fluon ${ }^{\circledR}$ (polytetrafluorethylene, De Monchy, The Netherlands), with cotton-sealed plastic tubes serving as nesting sites. The colony was fed twice a week with a standardized diet containing a 0:4 ratio of total proteins to digestible carbohydrates (diet modified from Dussutour and Simpson 2008) and house crickets (Acheta domesticus, QB Insects, Linnich, Germany). Water was provided ad libitum.

For timed egg collections, 15 queens were removed from the colony using a fine brush and placed in a Fluon-coated petri dish $(\varnothing=15 \mathrm{~cm}$, height $=1.5 \mathrm{~cm})$ containing a $2 \mathrm{~cm}^{2}$ piece of black cardboard to nest underneath. Queens were provided with 80 workers from their colony, a piece of food and a water tube. Queens were left to lay eggs for either 6 hours (for egg developmental stages up to stage 8) or 12 hours (stages 9-17), after which the queens were gently removed and placed back in the colony. Egg depositions were either collected at the same time as queen removal (for stages 1 and 2) or aged in the petri dish (for stages 3 and onwards), with workers tending them. Food replaced daily, and petri dishes containing aging eggs were kept at the same temperature and humidity condition as the stock colony. Eggs were then collected at the desired stage and fixed.

Larval and pre-pupa stages used for morphometric analyses were collected from two subcolonies established by splitting in half the colony used for egg depositions. The first sub-colony, containing approximately 50 queens, was used to collect $1^{\text {st }}$ larval instars of unknown caste, $2^{\text {nd }}$ and $3^{\text {rd }}$ worker larval instars and worker pre-pupae. The second sub-colony, dequeened at the time of its 
establishment in order to trigger the production of new reproductives, was used to collect $1^{\text {st }}$ larval instars of unknown caste, $2^{\text {nd }}$ and $3^{\text {rd }}$ reproductive larval instars and reproductive pre-pupae.

Individual larvae and pre-pupae were collected using a fine brush and gently lined up, with the cephalic capsule facing up, on a piece of double-side tape which was then placed on a microscope slide for imaging.

Embryo fixation and nuclear staining. Eggs were gently transferred with a moistened brush in an incubation basket with a $100 \mu \mathrm{m}$ mesh (Intavis Bioanalytical Instruments AG), dechorionated in $25 \%$ commercial bleach (Klorin, Colgate-Palmolive A/S) bath for 2 minutes and quickly washed under demineralized tap water for 30 seconds. Eggs were then bathed in $0.3 \%$ PBTx $(1 \times$ PBS, Triton X-100 - Sigma Aldrich) for 5 minutes on ice, heat fixed by boiling for 15 seconds in $0.3 \%$ PBTx, quickly quenched in $1 \mathrm{x}$ PBS on ice and finally bathed in $0.1 \%$ PBTw $(1 \mathrm{x}$ PBS, Tween-20 Sigma Aldrich) on ice for 5 minutes. Eggs were then washed 4 times in PBTw (5 minutes each wash), fixed in $4 \%$ paraformaldehyde for 30 minutes and then washed 3 times in $1 \mathrm{x}$ PBS. Fixed eggs were transferred from the incubation basket to a $2 \mathrm{ml}$ screw top clear glass vial (Supelco; Sigma-Aldrich) using a glass Pasteur pipette. After removing the $1 \mathrm{x}$ PBS, $500 \mu 1$ of ice cold methanol were added and the vial was vigorously shaken for 10 seconds to induce vitelline membrane cracking (methanol-shock). Embryos were finally washed 2 times with ice cold methanol and either stored at $-20{ }^{\circ} \mathrm{C}$ or immediately rehydrated. Embryos were rehydrated through a series of methanol/PBTw dilutions $(75 \%, 50 \%, 25 \%)$, and finally washed 3 times in PBTw. After removing the PBTw, embryos were incubated with a single drop of VectaShield mounting medium with DAPI (Vector Laboratories) for 10 minutes at $4{ }^{\circ} \mathrm{C}$ in dark. Fixed, DAPI counterstained embryos were transferred along with the mounting media onto a microscope slide, covered with a cover slip and imaged.

nanos and engrailed in situ hybridization. Monomorium pharaonis nanos and engrailed were cloned using: nanos forward primer 5'AAACGCTCTGTTTCCCCTCAA 3'and nanos reverse primer 5'GCGTTTGCTGTGCTTATGCTA3', and engrailed forward primer 5'CTAGTACGGTCTGCGACTA3' and engrailed reverse primer 5'CGCTTGTTCTGAAACCAGAT3', from a Monomorium pharaonis embryonic cDNA library. The nanos fragment was ligated into a PGEMTeasy vector and transformed into DH5 competent cells. Colonies were picked and then purified using Qiagen miniprep kit, after which they were sent for sequencing (Genome Québec). in situ hybridization RNA probes were generated by labelling T7 polymerase transcribed nanos plasmid with biotin and purifying using phenol-chloroform. in situ hybridizations were performed using an InsituPro VSI automated robot (Intavis) using a protocol previously described (Khila and Abouheif 2009).

Embryo imaging. DAPI-counterstained embryo images were captured at 20x magnification on an upright Olympus BX63F fluorescence microscope (Tokyo, Japan) equipped with a Retiga 6000 camera system (QImaging, Surrey, British Columbia, Canada) using cellSens Dimension software version 1.16. For each embryo, a series of Z-stack images were acquired (step), going from one side to the other. Z-stack images were then deconvolved (Gaussian) and only relevant stacks were selected to create either a maximum or an average intensity projection z-stack image. Images were further processed in Adobe Photoshop CC to optimize brightness and contrast, and to polish the background. For each collection time, representative embryos were selected according to the number of embryos in the slide showing similar developmental stage.

For differential interference contrast (DIC) images and videos, eggs were collected from the stock colony using a fine brush, placed on a microscope slide and gently covered with a cover slip. 
Drops of voltalef halocarbon oil 700 (Sigma-Aldrich) were released on the side of the cover slip, so that oil could slowly displace air and submerge the eggs. Eggs were imaged using the same protocol described for DAPI counterstained embryos. For videos, pictures were taken at different focal points every 20 minutes.

Larvae and pre pupae measurements. Larva and pre-pupa pictures were acquired using a BK plus lab system (Dun, Inc, Virginia, USA) equipped with a Canon 7D camera. Z-stack images were taken for each individual and combined using the software Zerene Stacker. Adobe Photoshop CC was used to measure the maximum cephalic capsule and larval length. We collected a total of 340 individuals, which were classified as follow: $1031^{\text {st }}$ instars (62 from queenless, 41 from queenright), $512^{\text {nd }}$ instar workers, $553^{\text {rd }}$ instar workers, 35 pre-pupa workers, $222^{\text {nd }}$ instar reproductives, $503^{\text {rd }}$ instar reproductives and 24 pre-pupa reproductives. We used morphological traits previously used in the literature for instar classification (hair types and their presence/absence; mandible coloration, etc.) Then, we plotted the $\log _{10}$ of both measurements to see whether our classification based on morphological traits corresponded to a clear classification based on morphometric data.

SEM microscopy. Representative instar larvae were collected from the two subcolonies used for larval collection and imaged using an environmental scanning electron microscope (FEI Inspect S SEM, Termo-Fisher Scientific). Images were taken in a low-vacuum, at an accelerating voltage of 7 $\mathrm{kV}$.

Pupal imaging. Pupal developmental series were obtained by isolating pre-pupae stages of reproductives and workers in fluon coated petri dishes. As soon as the individuals pupated, they were imaged on consecutive days using the same equipment and procedure as described for larvae and pre-pupae image acquisition.

DATA AVAILABILITY. The data that support the findings of this manuscript are available upon reasonable request.

\section{RESULTS}

\section{Embryonic development}

Under our experimental conditions (see Materials and Methods), M. pharaonis embryonic development lasted approximately 10 days, and freshly hatched $1^{\text {st }}$ instar larvae were never observed before 11 days after egg laying. We harmonized our descriptions of the developmental stages of $M$. pharaonis embryogenesis to the 17 embryonic stages characterized for the fruit fly Drosophila melanogaster (Campos-Ortega and Hartenstein 2013) by identifying and matching homologous developmental milestones in M. pharaonis. The approximate duration of each embryonic stage is denoted in parenthesis as time interval between the end of the previous stage and the beginning of the subsequent stage. Morphological features described in each stage were based on the analysis of DAPI counterstained embryos (Figure 1, Figure 2), as well as bright microscopy images (Figure 3), and differential interference contrast (DIC) time-lapse videos of living embryos (Supplementary video 1 ).

Stage 1. (0 to approximately 6 hours after egg laying). Freshly laid eggs are approximately $292 \pm 21 \mu \mathrm{m}$ long and $187 \pm 18 \mu \mathrm{m}$ wide (mean $\pm \mathrm{SD}, N=36$ ). The anterior pole is more rounded than the posterior pole, which is more pointed. The four female meiotic products are located near the anterior part of the egg cytoplasm. Upon fertilization, one of the four female meiotic products (the future female pronucleus) and the male pronucleus localize together in the 
interior of the egg ("PNi", Figure 1A), fuse and form the first zygotic nucleus. The other three female meiotic products (polar bodies - "PB", Figure 1A), remain in the cortical region of the egg. Under bright microscopy, the yolk appears fine and uniform in color and a small empty space is visible between the vitelline membrane and the egg cytoplasm at the posterior pole (Figure 1A). Stage 1 lasts until the end of the first two cleavage divisions, with the resulting four zygotic nuclei located in the center of the yolk (Figure 3B). Finally, at this stage we detect the highly conserved germline marker nanos marking the posterior pole of the embryo (Figure 4a).

Stage 2. (approximately 6 to 16 hours after egg laying). Stage 2 starts at the beginning of the $3^{\text {rd }}$ cleavage cycle and terminates at the end of the $8^{\text {th }}$ cleavage cycle, when the embryo consists of a syncytial blastoderm of 256 nuclei. The first synchronous nuclear divisions occur in the central part of the yolk, until 64 nuclei are formed (Figure 1C). Shortly after, nuclei begin to migrate towards the periphery of the egg (Figure 1D). Under bright field microscopy, the yolk is now lighter in color during the nuclear divisions and migration progress (compare Figure $3 \mathrm{~A}$ and 3B). The synchronized nature of the nuclear divisions can be observed in DIC time-lapse of living embryos, as each division leads the embryo to expand and contract rhythmically (Supplementary video seconds 1 - 2). At this stage the germplasm is shifted dorsally (Figure 4b).

Stage 3. (approximately 16 to approximately 20 hours after egg laying). Stage 3 spans the period between the last nuclear divisions and the arrival of the energids (nuclei with associated cytoplasm) at the surface of the yolk (Figure 1E, Figure 3C, Supplementary video seconds 3 - 4). The distribution pattern of the energids at the periplasm is uniform. Surprisingly, unlike Drosophila melanogaster, we did not observe the formation of morphologically differentiated pole cells during this stage.

Stage 4. (approximately 20 to approximately 25 hours after egg laying). Stage 4 is characterized by the formation of the germdisc. This is the result of a rapid migration of the blastoderm nuclei away from the dorsal region of the egg that results in the formation of a compact aggregation of blastoderm nuclei (the germdisc) on the lateral and ventral regions at the posterior pole of the egg (Figure 1F, G and G'; Figure 3D, E; Supplementary video seconds 4 to 5). Blastoderm nuclei on the lateral and ventral sides will give rise to the embryo proper. At the most dorso-anterior region of the egg, the plasmalemma, which is the membrane that envelopes the yolk and the developing embryo, appears to bulge out (Figure 3E). At this time the blastoderm energids that will later be part of the two extra-embryonic tissues - amnion and serosa - are likely differentiating. However, without markers, it is not possible to clarify the exact boundaries between serosa, amnion, and germdisc.

Stage 5. (approximately 25 to approximately 36 hours after egg laying). Stage 5 is characterized by the completion of the cellularization of the blastoderm and by a series of morphogenetic movements in the dorsal and postero-ventral regions. Initially, the most posteroventral region of the germdisc folds towards the dorsal side (Figure 1H, Figure 3F). This movement, in some embryos, appears to concurrently drag specific cell clusters from the posterior and postero-ventral regions of the blastoderm within the interior of the yolk sac (Figure 1I, $1 \mathrm{~J}$ and 1J'; Supplementary video 1 seconds 6-7). As the folding point appears to be where the primordial germ cells are localized (Figure 1H-J'; Figure 3F; Figure 4C), it is plausible that this morphogenetic movement is required to internalize the future germ line (Figure $1 \mathrm{~K}-\mathrm{K}$ '). However, other embryos during the same time point display a different pattern. Rather than internalized, potential germ cells are located over the folding ectoderm slide over and localize as a visible protrusion at the posterior pole of the egg (Figure 1L-M; Figure 3G,H; Figure 4D). This cell cluster appears similar to the protruding pole cells that are normally observed in $D$. melanogaster stage 3 , which we did not detect during stage 3 in $M$. pharaonis. The result of these processes may lead to two morphologically distinct embryo types: one type displaying the germ cell cluster protruding at the 
posterior pole (Figure 1L, L' and M; Figure 3G, H; Figure 4D) and another type lacking this cluster at the same position and instead show internalized germline progenitor cells (Figure 1K, K', Figure 3I, Figure 4C). Once the postero-ventral folding of the germdisc is completed, the dorsal region of the blastoderm begins to detach from the vitelline membrane in a postero-anterior direction (Figure $3 \mathrm{G}$, Supplementary video seconds 6 to 7). Stage 5 ends when this process is completed.

Stage 6. (approximately 36 to approximately 42 hours after egg laying). Stage 6 encompasses gastrulation. It begins when the lateral ectodermal plates break contacts with the presumptive mesoderm, which appears as a stiff plate ("EP" and "M", respectively, in Figure 1N). The lateral ectodermal plates rapidly slide towards the ventral side, eventually fusing on top of the mesoderm at the midline (Figure 1O, Figure 3J). By the end of this process, the developing embryo consists of a three-layered germ band located ventral to the yolk sac. However, with the current methodologies it is unclear if endoderm formation and thus the entire process of gastrulation is complete by the end of stage 6 (Supplemental video seconds 8-16).

Stage 7. (approximately 42 to approximately 48 hours after egg laying). Stage 7 is characterized by the end of gastrulation and initiation of germ band elongation along the anteroposterior axis of the egg (Figure 1P, Figure 3K, Supplementary video seconds 17 - 46). The dorsal side of the yolk sac is likely covered by the amnion (Figure 1P'). By the end of this stage, the bulbous swellings formed at the anterior pole during stage 4 through the plasmalemma expansion appear to pinch off as vesicles. These vesicles appear similar to serosa cells and float in the space between the embryo and the vitelline membrane.

Stage 8. (approximately 48 to approximately 66 hours after egg laying). During stage 8 the germ band continues to elongate towards the dorsal side of the egg from both directions (Supplemental video seconds 47 - 82). Transient segments are visible on the mesoderm (Figure 1Q). At this stage we begin to see a thickening of the anterior of the germband, where the future head lobes start to be visible (Figure 1Q') and at the end of the stage the germ band has reached approximately $80 \%$ of its final length (Figure $1 \mathrm{R}$ and Figure $3 \mathrm{~L}$ ). The serosa cells that had expanded in the previous stage are located in the anterior part of the egg, and often shift dorsally, as they are pushed by the growing head structures (Figure 3L). The germline precursor cells are located in the interior of the germ band, in the last abdominal segment (Figure 4E).

Stage 9. (approximately 66 to approximately 80 hours after egg laying). Stage 9 is characterized by the completion of germband extension, where the germband has reached its maximum extension, and now it covers the yolk sac, as the tip of the future abdomen is almost in contact with the posterior end of the head (Figure 2A-C and Figure 3M, Supplemental video seconds 83 -99). The parasegments from stage 8 are no longer visible. A thin ridge of mesectodermal cells runs down from the head to the posterior end of the abdomen at the ventral midline of the embryo.

Stage 10. (approximately 80 to approximately 92 hours after egg laying). During stage 10 the bilateral lobes of the head expand considerably, and a series of grooves run perpendicularly to the embryonic midline, creating separation between the body segments. Segments appear almost simultaneously but become more and more defined from the anterior to the posterior end of the germ band. These observations are supported by engrailed (en) expression, a developmental regulatory gene that marks the posterior half of each segment in insects. At this stage, en shows that although all segments are present simultaneously, they are more strongly expressed in the most anterior segments and faintest in the most posterior segments (Figure 4i). The stomodaeum ("sd", Figure 2E) arises as an ovoidal invagination between the antennal lobes (Figure $2 \mathrm{D}-\mathrm{F}$, Figure $3 \mathrm{~N}$ ). The primordial germ cells are located in the last abdominal segment (Figure 4E, $\mathrm{G) \text {. }}$ 
Stage 11. (approximately 92 to approximately 168 hours after egg laying). Stage 11 is characterized by the completion of segmentation, where all segments of the embryos become well defined (Figure $4 \mathrm{j}$ ). The future gnathal appendages (mandible, maxilla and labium; "md", "mx" and "la", Figure 2G) grow as laterally rounded bulges pointing towards the posterior of the egg. The stomodaeum deepens, and the labrum begins to form as an ovoid protrusion of tissue immediately posterior to the stomodaeum ("lb", Figure $2 \mathrm{H}$ ). The remaining embryonic segments (the three thoracic segments and the ten abdominal segments) are visible in succession from anterior to posterior (Figure 2G, Figure 3O). The ridge of mesectodermal cells still runs as a thin band on the embryonic midline (Figure $2 \mathrm{H}, \mathrm{H}^{\prime}$ ). Towards the end of the stage, tracheal pits appear in the second and third thoracic segments, as well as in the abdominal segments (Figure 2I). The gnathal segments continue to grow laterally, but they slowly start to point towards the ventral side of the embryo (Figure 2I, J). The labrum grows considerably (Figure 2J, Figure 3P). A ventral midline groove appears where the ridge of mesectodermal cells was located (Figure 2J, K).

Stage 12. (approximately 168 to approximately 192 hours after egg laying). Stage 12 is characterized by the start germband retraction, where the posterior end of the germband retracts away from the posterior end of the head. The gnathal segments are oriented ventrally and are condensed. The proctodeal invagination becomes visible (Figure 2L, M, Figure 3Q, Q' and Figure $4 \mathrm{k}$ ). During this stage en expression is uniform in intensity in all segments. In some embryos, the germ cell population is no longer present in the last abdominal segment (Figure 4H).

Stage 13. (approximately 192 to approximately 200 hours after egg laying). Stage 13 is characterized by the end of germband retraction and the start of dorsal closure. At this time the posterior of the germband has fully retracted. Dorsal closure begins, with the flanking regions of the germ band progressively grow towards the dorsal side (Figure 2N, Figure 3R).

Stage 14. (approximately 200 to approximately 204 hours after egg laying). During stage 14 the gnathal segments, as well as the labrum, orient towards the anterior pole of the egg, as the head is moving towards the ventral side. Optic lobes are embedded in the head capsule. Dorsal closure proceeds (Figure 2O, P; Figure 3S).

Stage 15. (approximately 204 to approximately 216 hours after egg laying). Stage 15 is characterized by the completion of dorsal closure, as the lateral flanks meet at the dorsal midline, fusing and closing the dorsal side of the embryo. The thoracic and abdominal segments narrow considerably. The gnathal appendages orient towards the ventral side of the egg (Figure 2Q, R). In the posterior region of the gut small black spots are visible in light microscopy (Figure 3T, T'). These are similar to oenocytes, which are white spots observable in the posterior abdominal segments of larval instars.

Stage 16. (approximately 10 days after egg laying). During stage 16 the embryo straightens and begins to move. The first thoracic segment is wider than the other thoracic segments. Gnathal appendages now orient ventrally. The serosa is no longer visible (Figure 2S, S'; Figure $3 \mathrm{U})$.

Stage 17. (approximately 11 days after egg laying). Stage 17 marks the end of embryogenesis. The fully formed $1^{\text {st }}$ instar larvae outgrow the chorion and hatch through a medial transverse rupture (Figure $3 \mathrm{~V}$ ).

\section{Larval development}

The number of larval instars in M. pharaonis was determined by plotting the maximum head width versus the maximum length along the antero-posterior axis of imaged larvae (Figure 5A,B), wherein each separated cloud of points correspond to a different instar. Pre-pupa individuals were also included. We confirmed that $M$. pharaonis has three larval instars, as previously described by Berndt and Eichler (1987) and Alvares and et al. (1993). During second and third instars, we could 
easily discriminate between reproductive and worker castes based on morphometric data and types of cuticular processes on the body. We could not, however, discriminate between male and female reproductives. Likewise, we could not find morphological traits allowing the discrimination between first instars belonging to different castes. Berndt and Eichler (1987) provided a thorough description of $M$. pharaonis larval instars. However, as the description is available only in the German language, we provided below a brief characterization of each larval instar based on the examination of representative SEM images (Figure 5C-G, Figure 6).

First instar (Figure 5C, Figure 6A-C): $1^{\text {st }}$ instar larvae are slightly longer on the major axis than a freshly laid egg (length \pm SD: $0.389 \pm 0.032 \mathrm{~mm}$ ), with an average head width of $0.142 \pm 0.006 \mathrm{~mm}(\mathrm{~N}=103$, Figure $5 \mathrm{~B})$. They are whitish in pigmentation and fat with a broader posterior (Figure 5A). The head is ventral at the anterior end, while the anus is postero-ventral. They have very few cuticular body hairs, which are simple in morphology and sparse (Figure 5C, Figure 6A). On the ventral side, the prothorax and the abdominal segments bear four short setae, roughly organized in two rows coasting the ventral midline (Figure 5C, Figure 6A-B). The second and third thoracic segments always lack the short hair in the inner row (Figure 6B), which is a distinct trait of this instar. The head is simple, with a slit-like opening at the border between the gena (the lower part of the head that extends behind the maxilla) and the prothorax (Figure 5C, Figure 6B). We observed four short hairs along the ventral border of the clypeus. At the anterior region of the labrum, there are 6 short setaceous sensillae, while at the ventral region of the labrum there are four small peg-like basiconic sensillae, which are sensory sensilla involved in chemoreception. At this stage we observe mandibles with one or two blunt teeth. The conical maxilla have basiconic sensilla on the galea, which are scoop-like structures located over the outer edge of the labrum. Finally, the elliptical labium has four setaceous and two basiconic sensillae on the ventral border.

Second instar (worker and reproductive): $2^{\text {nd }}$ instar worker-destined larvae have an average length of $0.572 \pm 0.090 \mathrm{~mm}$ and an average head width of $0.173 \pm 0.008 \mathrm{~mm}(\mathrm{~N}=51$, Figure $5 B)$. They are whitish in pigmentation and more slender than a $1^{\text {st }}$ instar at the posterior end (Figure 5A). The location of the anus is sub-terminal. We observed numerous long and simple body hairs, rarely bifid, that are mostly uniformly distributed and organized in rows along the segmented body (Figure 5D, Figure 6D-E). Unlike in the $1^{\text {st }}$ instars, hairs are present on the midline of the ventral surface. We observed few simple and sparse hairs on the head. The antennae contain three basiconic sensilla (Figure 6F). Each half of the labrum has 4 short setaceous sensilla on the anterior part, one small basiconic sensilla on the ventral side and two basiconic sensilla on the most ventro-posterior end. Moreover, each maxillary palp bears one short, simple hair, 2-3 basiconic sensilla and one setaceous sensilla, whereas the galea bears two small basiconic sensilla. The labium contains four sensilla on the ventral border. Finally, each labial palp bears two small basiconic sensilla on top, and one basiconic sensilla between each palp and the opening of the sericteries, which is positioned behind the labial palp and the pseudopalp.

Second instar reproductive-destined larvae have an average length of $1.026 \pm 0.192$ $\mathrm{mm}$ and head width of $0.215 \pm 0.004 \mathrm{~mm}(\mathrm{~N}=22$, Figure 5B). They are whitish in pigmentation and much fatter at the posterior end compared to a $2^{\text {nd }}$ instar worker-destined larvae (Figure 5A, E). Unlike $2^{\text {nd }}$ instar worker-destined larvae, we found no hairs on thoracic and abdominal segments, with the exception of the prothorax that bears few short, simple hairs on the ventral side (Figure 5E). Moreover, we observed few simple and sparse hairs on the head, organized in a similar fashion to $2^{\text {nd }}$ instar worker-destined larvae. Finally, the clypeus and mouth parts are also similar, in terms of shape and sensilla number and type, to that described in the $2^{\text {nd }}$ instar worker-destined larvae (Figure 6I). 
Third instar (worker and reproductive): $3^{\text {rd }}$ instar worker-destined larvae have an average body length of $1.551 \pm 0.432 \mathrm{~mm}$ and an average head width of $0.273 \pm 0.009 \mathrm{~mm}(\mathrm{~N}=55$, Figure 5B). They are whitish in pigmentation, but unlike previous instars the gut pigmentation is becoming increasingly darker and mandibles are now pigmented (Figure 5A). We observed numerous bifurcated, anchor-shaped hairs on thoracic and abdominal segments, organized in rows following body segmentation similar to $2^{\text {nd }}$ instar worker-destined larvae (Figure 5F, Figure $6 \mathrm{H}$ ). Moreover, we observed bifid and sometimes trifurcated hairs around the anus, while there are anchor-shaped and bifid hairs on the cranium (Figure 5F, Figure 6G). The antennae contain three small basiconic sensilla. Finally, the clypeus and mouth parts are similar, in terms of shape and sensilla number and type, to that described $2^{\text {nd }}$ instar worker-destined larvae (Figure 6G).

Third instar reproductive-destined larvae have an average body length of $2.464 \pm$ $0.397 \mathrm{~mm}$ and an average head width of $0.284 \pm 0.014 \mathrm{~mm}(\mathrm{~N}=50$, Figure 5B). They are whitish in pigmentation, and similar to $3^{\text {rd }}$ instar worker-destined larvae the gut pigmentation becomes increasingly darker while ageing and pigmented mandibles (Figure $5 \mathrm{~A}$ ). Similar to $2^{\text {nd }}$ instar reproductive-destined larvae they are much fatter than $3^{\text {rd }}$ instar worker-destined larvae and have a noticeably large prothoracic segment. We observed extremely short, straight hairs on thoracic and abdominal segments, that can only be detected using SEM microscopy (Figure 5G). The cranium possesses almost no hairs, and what is there is organized in a similar fashion to those described in the $2^{\text {nd }}$ instar reproductive-destined larvae (Figure $6 \mathrm{~J}$ ). Moreover, the antennae are located in a round shape depression, with two or three basiconic sensilla. The mouth part sensilla and hair organization is similar to $2^{\text {nd }}$ instar reproductive-destined larvae, with the exception that each labium palp has three basiconic sensilla. Finally, the mandibles increasingly darken while ageing.

\section{Pupal development}

Under our experimental conditions, pupal development took a total of 12 days, and there was no difference across castes in the time of eclosion. Pupal development for M. pharaonis was determined by imaging individual worker and reproductive pupae as they aged from pupation to eclosion as adults. Here, we describe the prepupal and pupal development of each M. pharaonis caste (worker, queen, male; Figure 5A and Figure 7). The pre-pupa stage, for both worker (average body length $\pm \mathrm{SD}: 1.576 \pm 0.070$; average head width $\pm \mathrm{SD}: 0.269 \pm 0.006, \mathrm{~N}=35)$ and reproductive (average body length $\pm \mathrm{SD}: 2.630 \pm 0.103$; average head width $\pm \mathrm{SD}: 0.279 \pm 0.010, \mathrm{~N}=$ 24, Figure 5B) individuals, can be easily distinguished from the larval stages as the cuticle undergoes an extensive shrinking process (Figure 5A). The cuticle becomes increasingly wrinkled, starting from the most posterior abdominal segments. Pre-pupae are white, and the gut is colorless due to the meconium being expelled at the end of the $3^{\text {rd }}$ instar stage.

M. pharaonis pupae (Figure 7) are exarate and "naked" (i.e. do not spin a silk cocoon upon pupation). Worker pupae are approximately $1.5 \mathrm{~mm}$ long, whereas queen and male pupae are longer (Figure 6). Pupae of all castes become increasingly darker as they age, seemingly at the same rate. Males and females can be easily distinguished from day 1 by some morphological features. Males display bigger, ovoidal eyes, whereas female eyes are smaller and more rounded. In males, antennae run almost parallel to the body for their entire length, whereas in female antennae display a more pronounced angle, so that only the last antennal segments contact the body. Males and queens possess three ocelli and two pairs of wings, which are absent in workers. As they age, pupae acquire the characteristic coloration of the adult form: queens have an orange-brownish head and thorax, and a black abdomen. Males, instead, are completely black. Pigmentation begins as early as day 2 for queens and male pupae, and day 3 for worker pupae. The pigmentation in all castes begins in the eyes, or eyes and ocelli for queen and male pupae. Eye pigmentation appears to occur earlier 
in male than queen or worker pupae. Following the eyes, pigmentation proceeds in the more posterior segments of the abdomen, followed by the thorax for all castes.

\section{DISCUSSION}

Here, we present for the first time in an ant a developmental staging scheme from egg to adult (Figure 8). We characterized the main morphogenetic events occurring during 17 stages of embryogenesis using fluorescent and light microscopy (Figure 8, green to blue shades). We further assessed, using the highly conserved germline marker nanos, the localization of the germ cells at different developmental stages to mark the posterior pole in embryos, and used the segment polarity gene engrailed to characterize the formation of segments. Finally, we added further information to the existing larval literature (Alvares et al. 1993; Berndt and Eichler 1987), using morphometric data and SEM and light microscopy, we characterized the three larval instars (Figure 8, red shades) and the prepupal and pupal stages of $M$. pharaonis castes (Figure 8, orange). Overall, development lasted approximately 45 days, with embryonic development lasting approximately 11 days, larval development approximately 22 days, and pupal development approximately 12 days. The ability to readily obtain queen and male-destined brood from, potentially, as early as the embryo to pupal stages is a rare feature that will benefit future studies on caste determination and sex-ratios, and make M. pharaonis is a great model for eco-evo-devo studies. Furthermore, major developmental events of M. pharaonis are conserved with Drosophila melanogaster and other holometabolous insects, which we discuss in detail below.

\section{Embryonic development}

The initial stages of $M$. pharaonis embryogenesis (fertilization, syncytial cleavage and arrival of the energids to the blastoderm surface) resemble the analogous stages described in other well-studied insects such as D. melanogaster (Campos-Ortega and Hartenstein 2013), Tribiolium castaneum (Handel et al. 2000) Gryllus bimaculatus (Donoughe and Extavour 2016) and Nasonia vitripennis (Bull 1982). Fertilization, including the union of gametes and subsequent mitosis, appear to be gonomeric and show striking similarities, in terms of polar bodies and pronuclei position, to that characterized in D. melanogaster (Loppin et al. 2015). A gonomeric type of fertilization is characterized by the independent formation of a mitotic spindle by each of the pronuclei, with kariogamy occurring only at the telophase of the first cleavage mitosis, and has been described in all assessed insects (Kawamura 2001). The ability of the female pronucleus to form an independent mitotic spindle and to undergo subsequent mitosis is also thought to facilitate haplodiploid parthenogenesis, which determines unfertilized eggs to develop into males (Kawamura 2001; Tram and Sullivan 2000). Furthermore, the cytogenetic mechanisms underlying haplodiploidy can theoretically allow any combination of gametes present in the egg to either fuse or not, explaining the sexual diversity across social insect lineages, where societies can comprise of only clonal males (Fournier et al. 2005) or females (Oxley et al. 2014), gynandromorphs or even females originating from the fusion of two male gametes (Aamidor et al. 2018).

Although the initial stages of embryonic development do not differ between M. pharaonis and D. melanogaster and other model insect organisms (e.g. synchronized nuclear subdivisions without cytoplasm cleavage, migration of nuclei to the surface of the egg for cellularization), notably, we did not observe the formation of morphologically distinguishable pole cells at the posterior pole of the embryo during stage 3, despite the localization of requisite germline marker nanos in this zone during stage 1 and 2 similar to D. melanogaster. However, this is a similar pattern to that which has been observed in the Dipteran moth midge Clogmia albipunctata (Jiménez-Guri et al. 2014).

After the arrival of energids at the periphery of the embryo at the end of stage 3 , the subsequent morphogenetic movements, including mesoderm formation, show striking similarities to 
what it has been described in the honeybee Apis mellifera (Fleig and Sander 1986; Fleig and Sander 1988). The blastoderm cells located in the dorsal and lateral sides move in ventral direction, forming a compact epithelium covering the ventral and ventro-lateral regions of the blastoderm. This movement leaves very few cells covering the dorsal region, which at this stage seems to adhere tightly to the vitelline membrane. The morphology of the dorsal region appear to be similar to the "dorsal strip" characterized in A. mellifera (Fleig and Sander 1986). While the blastoderm cells constituting the embryo proper coalesce towards the ventral side, at the anterior pole we observed the formation of big cells that progressively increase in size and eventually pinch off after gastrulation is completed. Once they pinch off, these cells appear to float relatively freely in the space between the developing embryo and the vitelline membrane, persisting in this space until, at least, stage 15 . The anterior pole of the embryo is, in many insects, the egg region where the blastoderm cells destined to form the serosa - one of the two extraembryonic tissues - originate (Panfilio 2008). The serosa often absolves a protective function, and gradually envelope the whole developing embryo, initially covering the dorsal side and finally surrounding the embryo proper on the ventral side (Panfilio 2008). A similar process is also observed in A. mellifera. However, in $M$. pharaonis, the serosa envelope appears to never form and for this reason we believe that the big cells forming at the anterior pole are serosa cells in origin, but eventually absolving a non-protective function later in embryonic development (Panfilio 2008).

In M. pharaonis, it appears that the dorsal and anterior region of the yolk sac are exclusively covered by the blastoderm cells originally located to the dorso-lateral side of the embryo. Right before gastrulation, the dorsal side detaches from the vitelline membrane starting from the posterior pole and progressively advances towards the anterior. The yolk, probably being consumed due to the high activity of the blastoderm cells forming the embryo proper in the ventral side, "sink". This "sinking" movement of the yolk leads the blastoderm cells located on dorso-lateral side of the embryo to cover the dorsal region, in what it appears a passive movement. Since in apocritan Hymenoptera the amnion - the second extraembryonic tissue - cover the yolk rather than the embryo and originate from the anterior and dorsal margin of the germ rudiment (Panfilio 2008), we are lead to believe that the dorso-lateral blastoderm cells represent the amnion cap. Future studies employing specific serosa and amnion markers, such as zen, are needed to elucidate how these two extraembryonic tissues form and develop in M. pharaonis (Rafiqi et al. 2008).

Another peculiarity of $M$. pharaonis development the movement involving the germ cells. At the time the blastoderm cells forming the embryo proper coalesce towards the ventral side, where the presumptive germ cells are located in a ventro-posterior region. From this position, we have observed that this predicted cluster of cells seem to acquire two distinct fates. In some embryos they appear to invaginate within the interior of the egg, close to the posterior pole, at the beginning of stage 5 (Figure 11-j', k'), which is also consistent with nanos expression (Figure 4c). In other embryos, they migrate over the ectoderm and are visible as a cluster of cells protruding at the posterior pole until stage 7 (Figure 11-m, Figure 3h, Figure 4d), in a fashion that resembles the position of the stage 3 pole cells in D. melanogaster (Campos-Ortega and Hartenstein 2013), although at a much later stage in development than D. melanogaster. Whether these two modes of germ cell migration represent an early divergence between reproductive and worker castes in $M$. pharaonis is an intriguing possibility that warrants further investigation.

Gastrulation in M. pharaonis appear to follow the "Hymenoptera type" reported for honeybees (Fleig and Sander 1986; Fleig and Sander 1988) and described by Lynch in $N$. vitripennis (Lynch et al. 2012). The process of gastrulation begins when the lateral ectodermal plates break contact with the cells positioned along the ventral midline. After this, the ectodermal plates slide from both sides on top of the presumptive mesoderm, which remains as a stiff plate. The developmental stages following gastrulation resemble those described in other insects. The 
germband extends rapidly towards the dorsal side of the egg, so that the tip of the head is almost in contact with the terminal part of the future abdomen. Segments appear to form almost simultaneously, in a typical long-germ mode of development as indicated by engrailed expression (Figure 4j-1) and previous reports of engrailed and wingless expression in Camponotus floridanus, Pheidole hyatti and Pheidole morrisi (Abouheif and Wray 2002, Rajakumar et al. 2018; Rafiqi et al. 2020). Germband retraction and dorsal closure are similar to the analogous processes described in D. melanogaster (Campos-Ortega and Hartenstein 2013).

Hatching appears to happen by a medial transverse rupture, when the first instar outgrow the chorion, in a similar manner to the fire ants (Fox et al. 2012). In some ants, such as the trap jaw ants of the genus Odontomachus, the larva chews its way out of the chorion (Fox et al. 2017).

\section{Larval development}

Previous studies have provided information regarding the number and morphology of larval instars in M. pharaonis, making use of both morphometric measurements (i.e. head width, body length, diameter of the first thoracic spiracle) and examination of types and number of cuticular features such as setae, spines and tuberculi (Alvares et al. 1993; Berndt and Eichler 1987). The combined use of these traits is often sufficient to determine the number of larval instars in ants (Masuko 2017). On the basis of these studies, M. pharaonis has been deemed to have three larval instars, and our data fully support this. In ants, the reported number of larval instars range from three to six (Solis et al. 2010; Alvordo et al. 2015; Rajakumar et al. 2018). Little information is available in terms of duration of each instar in this species, as it is often difficult to obtain direct observation of larval moulting. Peacock and Baxter (1950) provided rough estimates in terms of duration of larval period, with an average larval development of 17 days for workers and 21.3 days for reproductives (gynes and males). However, Alvares et al. (1993) reported that worker larval development can range between 10 and 21 days. This is not surprising, as wide variation in terms of larval developmental time are expected due to the complete dependence of the larvae from workers in terms of nutrition. Furthermore, other factors such as temperature and humidity could influence their development. The more interesting feature of M. pharaonis larvae is the clear morphological difference between reproductive and worker larvae upon the $1^{\text {st }}$ instar moulting: reproductives present few to almost no hairs on thoracic and abdominal segments, while workers have several. The lack of hairs in reproductive larvae is something relatively unique, to the best of our knowledge. Third instar larvae of all castes display pigmented sclerotized mandibles and a gut coloration that becomes progressively darker with age. These reflect the type of food that the different larval stages receive from workers. While first and second instar larvae are fed with liquid food via trophallaxis, third instars are fed mostly with solid chunks of food (Haack et al. 1995). In particular, third instar larvae are responsible for processing and redistributing proteinaceous food to the rest of the colony (Haack et al. 1995). The ability to perform this function can also explain why old larval stages are usually placed on the outskirts of the brood piles, as in this way processed proteinaceous food can flow inwards (Lim and Lee 2005). The "social stomach" function performed by old instar larvae in M. pharaonis has been showed to also have an effect on queen fecundity (Børgesen 1989; Børgesen and Jensen 1995) and the production of new reproductives (Warner et al. 2016).

\section{Pupal development}

Since their origin approximately 479 million years ago, insects have evolved a diversity of postembryonic developmental trajectories including amatoboly, in which the developing individual is a miniaturized version of the adult; hemimetaboly, in which juvenile-nymphs are phenotypically similar to respective adult forms; and holometaboly, in which larvae form has no resemblance to the 
adult form and during the last larval instar undergo complete metamorphosis to transform into the adult form (Urena et al 2016, Truman and Riddiford 2019). The defining feature of the complete metamorphosis of holometabolous insects is the pupal stage. A rich history exists in the ant literature characterizing the morphological progression and internal structures of pupal development. The length of pupal development varies greatly across ant lineages (Wheeler and Wheeler 1973, Lommelen 2003, Ishii 2005), ranging from 12-18 days in the pavement ant Tetramorium caespitum, 23 days in Cryptocerus rohweri, and up to 36 days in the ponerine ant Pachycondyla obscuricornis. In M. pharaonis, we observed that pupal development lasted 12 days. Whether this relatively short developmental time may facilitate their invasive life history remains to be determined in a broader phylogenetic framework.

Of all ontological stages in ants, the pupal stage appears to be the least studied in terms of functional analysis of ant development and evolution. While functional studies exist that utilize embryos (Yan et al. 2017, Trible et al. 2017, Chiu 2020, Rafiqi et al. 2020), larvae (Penick et al. 2012, Alvarado et al. 2015, Rajakumar et al. 2018, Chandra et al. 2018), and adults (Simola et al. 2015 ) to test the molecular basis for ant innovations and social evolution, very little work has utilized the pupal stage to test hypotheses of social evolution. Fundamentally, pupal development represents a hotspot for tissue morphogenesis (Gotoh et al. 2016). Ants show incredible diversity in head, mandible, thoracic, and petiole morphology, therefore, the pupal stage will be of considerable interest for further developmental characterization. From a technical standpoint, the pupal stage provides some unique opportunities as the cuticle has not yet fully sclerotized and hardened. Simola et al. utilized the soft cuticle of the pupae to perform tissue specific injections of pharmacological inhibitors to test the molecular basis of intra-caste specific behaviors (Simola et al. 2015). Furthermore, in Nasonia, Tribolium, and Onthophagus, parental RNAi is routinely performed at the pupal stage prior to mating to allow for maternal effects to be tested (Lynch 2006, Lynch 2011, Miller 2012, Wasik 2012, Linz 2014). The largest technical hurdle for the adoption of such methodologies in ants is the inability in most ant systems to mate newly eclosed queens and males in the lab, which often require mating flights. However, this challenge does not exist in $M$. pharaonis because reproductives can be mated artificially within the lab either with siblings or with reproductives from another colony. Therefore, queen or male pupae can be injected during pupal development and then mated together to develop specific crosses to test the function of specific genes.

\section{CONCLUSION}

Providing a description and staging scheme for embryogenesis and a morphological characterization of larval and pupal development represents a crucial step to conduct eco-evo-devo studies of ant phenotypic diversity. Studies aiming at examining the function and/or the timing of expression of genes putatively involved in caste determination can use, for instance, the wild-type morphological description to select the correct developmental stage to investigate, or to understand how the phenotype changes in response to a genetic manipulation. The adoption of genetic manipulation technologies in ants, such as RNA-interference and CRISPR, also require that duration of specific embryonic stages, such as the syncytial cleavage phase, are well defined in order to be effective (Trible et al. 2017; Yan et al. 2017; Rajakumar et al. 2018; Rafiqi et al. 2020). A potential barrier that may have prevented the previous establishment of a developmental table for ants, is the difficulty in characterizing the various stages of embryonic development. However, the means to complete future developmental tables is widely accessible, requiring as a base only a fluorescent vital dye and a light/fluorescent microscope. We hope that our detailed characterization of the ontogeny of $M$. pharaonis will serve as a blueprint to provide other researchers with standardized descriptions for their favorite ant species or genera. 


\section{ACKNOWLEDGEMENTS}

We would like to thank the Abouheif lab for the comments on the manuscript. LP, RSL and GZ are funded by by Lundbeck Fellowship (R190-2014-2827). EA is funded by a NSERC Discovery grant (Canada) and AR by a FRQNT fellowship (Quebec), AMR by a grant BAP11.2018/20 (Turkey).

\section{AUTHOR CONTRIBUTIONS}

LP, AR, EA and GZ conceived the project. LP, AR, EA and GZ designed experiments. LP, AR and RSL performed experiments. LP and AMR matched ant embryonic descriptions to Drosophila. LP and AR wrote manuscript with input from co-authors. LP and AR contributed equally.

\section{FIGURE CAPTION}

Figure 1. M. pharaonis embryonic development (Stage 1-8). Fluorescence images with DAPIcounterstained nuclei are showed. Anterior egg pole is to the left. Different letters indicate different embryos. Developmental stage is indicated on the top-right corner. Views (Dorsal, Ventral, Lateral) are indicated in the bottom-right corner of the picture. (A), (B), (C) and images where views are preceded by “*” are maximum intensity projections of Z-stack images taken at the sagittal plane. All other images are maximum intensity projections of Z-stack images taken at the surface of the embryo. In $(\mathrm{H})$, white arrow indicates the postero-ventral folding of the germ primordium. In all other images, white arrows point to the location of the presumptive germ cluster. White asterisks indicates the lack of the presumptive germ cell cluster. Scale bar for all images is showed in (A).

Figure 2. M. pharaonis embryonic development (Stage 9-16). Fluorescence images with DAPIcounterstained nuclei are shown. Anterior egg pole is to the left. Different letters indicate different embryos. Developmental stage is indicated on the top-right corner. Views (Dorsal, Ventral, Lateral) are indicated in the bottom-right corner of the picture. All images are maximum intensity projections of Z-stack images taken at the surface of the embryo. Scale bar for all images is shown in $(\mathrm{A})$.

Figure 3. M. pharaonis embryonic development (Stage 1-17). DIC images of embryos at different stage of development are shown. Anterior egg pole is to the left. Different letters indicate different embryos. Developmental stage is indicated on the top-right corner. Views (Dorsal, Ventral, Lateral) are indicated in the bottom-right corner of the picture. (A), (B), (C) and (Q') are individual images taken at the sagittal plane. All other images are composite Z-stack images taken at the surface of the embryo. Scale bar for all images is shown in (A).

Figure 4. Germ cell and segment formation during embryonic development of $M$. pharaonis. Embryos at different stages of development stained for nanos mRNA to visualize the position of germ cells (A-H) or engrailed mRNA to visualize segment boundaries (I-K). (A) Embryo at early stage 1 (see text) showing the proper formation of the germ plasm at the posterior pole of the embryo. (B) Embryo at stage 2 showing germplasm migrating dorsally. (C) Embryo at stage 5 showing the germ cell cluster at the folding point of the germ primordium. (D) Embryo stage 5 embryo showing the germ cell cluster protruding at the posterior pole. (E) and (F) are stage 8 and 10 embryos, respectively, displaying the germ cells in the terminal abdominal segment. (G) Dorsal view of embryo at stage 10 showing germ cell cluster. (H) Embryo at early stage 12 lacking the germ cell cluster. (I), (J), and (K) are stage 10, 11, and 12 embryos showing simultaneous formation of segments along the germband. 
Figure 5. Morphometric and morphological characterization of $M$. pharaonis larval instars. (A) Examples of light microscope images of larval instars showing changes in pigmentation and gross morphology during larval development. (B) Relationship between maximum head width (HW) and larval length (LL), expressed as $\log _{10} \mu \mathrm{m}$, in 340 larval and pre-pupa stages of $M$. pharaonis. Error bars represent standard deviation. Worker (triangles) and reproductive (squares) individuals were assigned to a specific instar or pre-pupa stages (color codes) by assessing overall size, morphology and chaetotaxy. Pictures below the plot show scanning electron microscope (SEM) images of (C) a first larval instar, (D) a second larval instar worker, (E) a second larval instar reproductive, $(F)$ a third larval instar worker and $(G)$ a third larval instar reproductive. Scale bar is $200 \mu \mathrm{m}$.

Figure 6. Detailed SEM images of worker and reproductive larvae. (A) 1st instar larvae ready to molt (B) Zoom-in of early 1st instar (C) Zoom-in of 1st instar larvae ready to moult. (D) Second instar worker larva. (E) Hairs under the cuticle. (F) Mouth parts zoom-in. (G) 3rd instar worker head capsule zoom-in. (H) Detail of the anchor hairs. (I) 2nd and (J) 3rd reproductive instar head zoom-ins. White stars indicate lack of the 4 hairs.

Figure 7 Pupal development. Front (upper rows) and lateral (lower rows) views of individual worker (top), gyne (middle) and male (bottom) for each day of pupal development until eclosion. Scale bar is $1 \mathrm{~mm}$.

Figure 8. Summary diagram of $M$. pharaonis life cycle. Green shades indicate hours after egg laying. Blue shades indicate days after egg laying. Red to Orange indicate weeks after egg laying. Grey indicates imago. $\mathrm{L}=$ lateral, $\mathrm{D}=$ dorsal, $\mathrm{V}=$ ventral.

\section{Supplemental files}

Supplemental video 1. Live imaging of M. pharaonis embryogenesis. MP4, Live imagining spans from egg deposition (st1) through gastrulation and germband extension (stage 9).

\section{REFERENCES}

Aamidor SE, Yagound B, Ronai I, Oldroyd Benjamin P (2018) Sex mosaics in the honeybee: how haplodiploidy makes possible the evolution of novel forms of reproduction in social Hymenoptera Biology Letters 14:20180670 doi:10.1098/rsbl.2018.0670

Abouheif E, Favé M-J, Ibarrarán-Viniegra AS, Lesoway MP, Rafiqi AM, Rajakumar R (2014) Eco-EvoDevo: The Time Has Come. In: Landry CR, Aubin-Horth N (eds) Ecological Genomics: Ecology and the Evolution of Genes and Genomes. Springer Netherlands, Dordrecht, pp 107-125. doi:10.1007/978-94-007-7347-9_6

Abouheif E, Wray GA (2002) Evolution of the gene network underlying wing polyphenism in ants Science 297(5579):249-252 doi: 10.1126/science. 1071468

Akam M (1998) Hox genes, homeosis and the evolution of segment identity: no need for hopless monsters The International Journal of Developmental Biology 42(3):445-451 PMID: 9654030

Alvarado S, Rajakumar R, Abouheif E, Szyf Moshe (2015) Epigenetic variation in the EGFR gene generates quantitative variation in a complex trait in ants Nature Communications 6(6513) doi:https://doi.org/10.1038/ncomms 7513

Alvares LE, Bueno OC, Fowler HG (1993) Larval instars and immature development of a Brazilian population of pharaoh's ant, Monomorium pharaonis (L.) (Hym., Formicidae) Journal of Applied Entomology 116:90-93 doi:10.1111/j.1439-0418.1993.tb01171.x

Arthur W (2002) The emerging conceptual framework of evolutionary developmental biology Nature 415:757-764 doi: https://doi.org/10.1038/415757a 
Béhague $\mathrm{J}$ et al. (2018) Lack of interruption of the gene network underlying wing polyphenism in an earlybranching ant genus Journal of Experimental Zoology Part B: Molecular and Developmental Evolution 330(2):109-117 doi:https://doi.org/10.1002/jez.b.22794

Bernadou A et al. (2018) Stress and early experience underlie dominance status and division of labour in a clonal insect. Proceedings of the Royal Society B: Biological Sciences 285:20181468 doi:https://doi.org/10.1098/rspb.2018.1468

Berndt K-P, Eichler W (1987) Die Pharaoameise, Monomorium pharaonis (L.) (Hym., Myrmicidae) Mitteilungen aus dem Museum für Naturkunde in Berlin Zoologisches Museum und Institut für Spezielle Zoologie (Berlin) 63:3-186 doi:10.1002/mmnz.19870630102

Bier K (1952) Beziehungen zwischen Nährzellkerngröße und Ausbildung ribonukleinsäurehältiger Strukturen Oocyten von Formica rufa rufo-pratensis minor Gößwald. Verhandlungen der Deutschen Zoologischen Gesellschaft in Freiburg. Akademische Verlagsgesellschaft Geest \& Portig K.G. 369374

Blochmann F (1892) Über das Vorkommen bakterienähnlicher Gebilde in den Geweben und Eiern verschiedener Insekten. Zbl Bacteriol 11:234-240

Børgesen LW (1989) A new aspect of the role of larvae in the pharaoh's ant society (Monomorium pharaonis (L.)-Formicidae, Myrmicinae): Producer of fecundity-increasing substances to the queen Insect Soc 36:313-327 doi: $10.1007 / \mathrm{bf02224883}$

Børgesen LW, Jensen PV (1995) Influence of larvae and workers on egg production of queens of the pharaoh's ant,Monomorium pharaonis (L.) Insect Soc 42:103-112 doi:10.1007/bf01245702

Brian MV (1974) Caste differentiation in Myrmica rubra: The role of hormones Journal of Insect Physiology 20(7):1351-1365 doi:https://doi.org/10.1016/0022-1910(74)90238-8

Buchner P (1918) Vergleichende Eistudien 1. Die akzessorischen Kerne des Hymenoptereneies Archiv für mikroskopische Anatomie 91:1-202 doi:https://doi.org/10.1007/BF02978932

Buchner P (1965) Endosymbiosis of Animals with Plant microorganisms John Wiley \& Sons, New York

Bull AL (1982) Stages of living embryos in the jewel wasp Mormoniella (nasonia) vitripennis (walker) (hymenoptera: pteromalidae) International Journal of Insect Morphology and Embryology 11:1-23 doi:https://doi.org/10.1016/0020-7322(82)90034-4

Campos-Ortega JA, Hartenstein V (2013) The Embryonic Development of Drosophila melanogaster. 2nd edn. Springer Berlin Heidelberg

Carroll SB (1995) Homeotic genes and the evolution of arthropods and chordates Nature 376(6540):479-485 doi: $10.1038 / 376479 \mathrm{a} 0$

Carroll SB (2008) Evo-devo and an expanding evolutionary synthesis: a genetic theory for morphological evolution Cell 134(1):25-36 doi: 10.1016/j.cell.2008.06.030

Chandra V et al. (2018) Social regulation of insulin signaling and the evolution of eusociality in ants Science 361(6400):398-402 doi:https://doi.org/10.1126/science.aar5723

Dewitz H (1878) Beitrage zur postembryonalen Gliedmassenbildung bei den lnsekten. Z. Wiss. Zool. 30:78105.

Donoughe S, Extavour CG (2016) Embryonic development of the cricket Gryllus bimaculatus Developmental Biology 411:140-156 doi:10.1016/j.ydbio.2015.04.009

Dussutour A, Simpson S.J (2008) Description of a simple synthetic diet for studying nutritional responses in ants Insectes Sociaux 55: 329-333 doi:10.1007/s00040-008-1008-3

Edwards JP (1987) Caste regulation in the pharaoh's ant Monomorium pharaonis: the influence of queens on the production of new sexual forms Physiological Entomology 12:31-39 doi:10.1111/j.13653032.1987.tb00721.x

Favé M-J et al. (2015) Past climate change on Sky Islands drives novelty in a core developmental gene network and its phenotpye BMC Evolutionary Biology 15(183) https://doi.org/10.1186/s12862-015$0448-4$

Fleig R, Sander K (1986) Embryogenesis of the honeybee Apis mellifera 1. (Hymenoptera : Apidae): An SEM study International Journal of Insect Morphology and Embryology 15:449-462 doi:https://doi.org/10.1016/0020-7322(86)90037-1

Fleig R, Sander K (1988) Honeybee morphogenesis: embryonic cell movements that shape the larval body Development 103:525-534 
Fournier D, Estoup A, Orivel J, Foucaud J, Jourdan H, Breton JL, Keller L (2005) Clonal reproduction by males and females in the little fire ant Nature 435:1230-1234

Fox EG, Smith AA, Gibson JC, Solis DR (2017) Larvae of trap jaw ants, Odontomachus LATREILLE, 1804 (Hymenoptera: Formicidae): morphology and biological notes Myrmecol News 25:17-28

Fox EG, Solis DR, Rossi ML, Delabie JHC, de Souza RF, Bueno OC (2012) Comparative Immature Morphology of Brazilian Fire Ants (Hymenoptera: Formicidae: Solenopsis) Psyche 2012:10 doi:10.1155/2012/183284

Ganin M (1869) Über die Embryonalhülle der Hymenopteren - und Lepidopteren-Embryonen Mémoires de l'Académie impériale des sciences de St. Pétersbourg 7e série 14(5) doi:https://doi.org/10.5962/bhl.title.1748

Gao Q et al. (In press) High-quality chromosome-level genome assembly and full-length transcriptome analysis of the pharoah ant Monomorium pharaonis GigaScience

Gilbert SF, Bosch TCG, Ledón-Rettig C (2015) Eco-Evo-Devo: developmental symbiosis and developmental plasticity as evolutionary agents Nature Reviews Genetics 16:611-622 doi:https://doi.org/10.1038/nrg3982

Gordon DM (2019) The Ecology of Collective Behavior in Ants Annual Review of Entomology 64:null doi:10.1146/annurev-ento-011118-111923

Gotoh A, Sameshima S, Tsuji K, Matsumoto T, Miura T (2005) Apoptotic wing degeneration and formation of an altruism-regulating glandular appendage (gemma) in the ponerine ant Diacamma sp. from Japan (Hymenoptera, Formicidae, Ponerinae) Development Genes and Evolution 215(2):69-77 doi:https://doi.org/10.1007/s00427-004-0456-7

Gotoh A, Billen J, Hashim R, Ito F (2016) Degeneration patterns of the worker spermatheca during morphogenesis in ants (Hymenoptera: Formicidae) Evolution \& Development 18(2):96-104 doi:https://doi.org/10.1111/ede.12182

Haack KD, Vinson SB, Olson JK (1995) Food Distribution and Storage in Colonies of Monomorium pharaonis (L.) (Hymenoptera: Formicidae) Journal of Entomological Science 30:70-81 doi:10.18474/0749-8004-30.1.70

Hall BK (2003) Evo-Devo: evolutionary developmental mechanisms The International Journal of Developmental Biology 47(7-8):491-495 PMID: 14756324

Handel K, Grünfelder CG, Roth S, Sander K (2000) Tribolium embryogenesis: a SEM study of cell shapes and movements from blastoderm to serosal closure Development Genes and Evolution 210:167-179 doi:10.1007/s004270050301

Hegner RW (1915) Studies on germ cells. IV. Protoplasmic differentiation in the oocytes of certain Hymenoptera Journal of Morphology 26(3):495-561 doi:https://doi.org/10.1002/jmor.1050260304

Hölldobler B, Wilson EO (1990) The Ants. Harvard University Press, Cambridge, Massachusetts

Hölldobler B, Wilson EO (2009) The Superorganism. New York: W.W Norton \& Company Inc.

Ishii Y, Kubota K, Hara K (2005) Postembryonic development of the mushroom bodies in the ant, Camponotus japonicus Zoological Science 22(7):743-753 doi:https://doi.org/10.2108/zsj.22.743

Jiménez-Guri E, Wotton KR, Gavilán B, Jaeger J (2014) A Staging Scheme for the Development of the Moth Midge Clogmia albipunctata Plos One 9:e84422 doi:10.1371/journal.pone.0084422

Kapheim KM et al. (2020) Developmental plasticity shapes social traits and selection in a facultatively social bee Proceedings of the National Academy of Sciences 117(24):13615-13625 doi:https://doi.org/10.1073/pnas.2000344117

Kawamura N (2001) Fertilization and the first cleavage mitosis in insects Development, Growth \& Differentiation 43:343-349 doi:doi:10.1046/j.1440-169x.2001.00584.x

Khila A, Abouheif E (2008) Reproductive constraint is a developmental mechanism that maintains social harmony in advanced ant societies Proceedings of the National Academy of Sciences 105:1788417889 doi:10.1073/pnas.0807351105

Khila A, Abouheif E (2009) In Situ Hybridization on Ant Ovaries and Embryos Cold Spring Harbor Protocols doi: 10.1101/pdb.prot5250

Khila A, Abouheif E (2010) Evaluating the role of reproductive constraints in ant social evolution Philosophical Transactions of the Royal Society B: Biological Sciences 365:617-630 doi:10.1098/rstb.2009.0257 
Klein A et al. (2016) Evolution of social insect polyphenism facilitated by the sex differentiation cascade PLoS Genetics 12(3):e1005952 doi: 10.1371/journal.pgen.1005952

LeBoeuf AC et al. (2016) Oral transfer of chemical cues, growth proteins and hormones in social insects eLife 5(e20375) doi:10.7554/eLife.20375

Lilienstern M (1932) Beiträge zur bakteriensymbiose der ameisen Zeitschrift Für Morphologie Und Ökologie Der Tiere 26(1/2):110-134

Lim S-P, Lee C-Y (2005) Brood arrangement and food distribution among larvae under different colony conditions in the Pharaoh's ant, Monomorium pharaonis (Hymenoptera: Formicidae) Sociobiology 46:491-503

Linksvayer TA, Fewell JH, Gadau J, Laubichler MD (2012) Developmental Evolution in Social Insects: Regulatory Networks from Genes to Societies Journal of Experimental Zoology Part B: Molecular and Developmental Evolution 318:159-169 doi:doi:10.1002/jez.b.22001

Linz DM, Clark-Hachtel CM, Borràs-Castells F, Tomoyasu Y (2014) Journal of Visualized Experiments 92:52059 doi:10.3791/52059

Londe $\mathrm{S}$ et al. (2015) Phenotypic plasticity and modularity allow for the production of novel mosaic phenotypes in ants EvoDevo 6(36) doi: https://doi.org/10.1186/s13227-015-0031-5

Loppin B, Dubruille R, Horard B (2015) The intimate genetics of Drosophila fertilization Open Biology 5 doi:10.1098/rsob.150076

Lynch JA, Desplan C (2006) A method for parental RNA interference in the wasp Nasonia vitripennis Nature Protocols 1:486-494 doi: https://doi.org/10.1038/nprot.2006.70

Lynch JA, Özüak O, Khila A, Abouheif E, Desplan C, Roth S (2011) The phylogenetic origin of oskar coincided with the origin of maternally provisioned germ plasm and pole cells at the base of the holometabola PLoS Genetics 7(4):e1002029 doi:https://doi.org/10.1371/journal.pgen.1002029

Lynch JA, El-Sherif E, Brown SJ (2012) Comparisons of the embryonic development of Drosophila, Nasonia, and Tribolium Wiley Interdisciplinary Reviews: Developmental Biology 1:16-39 doi:doi:10.1002/wdev.3

Masuko K (2017) Larval instars of the ant Strumigenys solifontis Brown (Hymenoptera: Formicidae): the fallacy of size distribution Journal of Natural History 51:115-126 doi:10.1080/00222933.2016.1254299

Metzl C, Wheeler DE, Abouheif E (2018). Wilhelm Goetsch (1887 - 1960): pioneering studies on the development and evolution of the soldier caste in social insects. Myrmecological News 26:81-96 doi: https://doi.org/10.25849/myrmecol.news 026:081

Miller SC, Miyata K, Brown SJ, Tomoyasu Y (2012) PLoS ONE 7(10):e47431 doi:https://doi.org/10.1371/journal.pone.0047431

Moczek AP et al. (2015) The significance and scope of evolutionary developmental biology: a vision for the $21^{\text {st }}$ century Evolution and Development 17(3):198-219 doi:10.1111/ede.12125

Nagel $\mathrm{M}$ et al. (2020) The gene expression network regulating queen brain remodeling after insemination and its parallel use in ants with reproductive workers Science Advances 6(38): eaaz5772 doi:10.1126/sciadv.aaz5772

Oettler J et al. (2019) Interruption points in the wing gene regulatory network underlying wing polyphenism evolved independently in male and female morphs in Cardiocondyla ants Journal of Experimental Zoology Part B: Molecular and Developmental Evolution 332:7-19 doi:https://doi.org/10.1002/jez.b.22834

Oxley PR et al. (2014) The Genome of the Clonal Raider Ant Cerapachys biroi Curr Biol 24:451-458 doi:https://doi.org/10.1016/j.cub.2014.01.018

Panfilio KA (2008) Extraembryonic development in insects and the acrobatics of blastokinesis Developmental Biology 313:471-491 doi:https://doi.org/10.1016/j.ydbio.2007.11.004

Patel NH (1994) Developmental evolution: insights from studies of insect segmentation Science 266(5185):581-590 doi: 10.1126/science.7939712

Passera L, Suzzoni JP (1979) The role of the queen of Pheidole Pallidula (Nyl.) (Hymenoptera, Formicidae) in the Brood sexualization after JH treatment Insect Sociaux 26: 343-353 doi:https://doi.org/10.1007/BF02223553

Peacock A, Baxter A (1950) Studies in pharaoh's ant, Monomorium pharaonis (L.) 3. Life history 
bioRxiv preprint doi: https://doi.org/10.1101/2020.12.22.423970; this version posted December 22, 2020. The copyright holder for this preprint (which was not certified by peer review) is the author/funder, who has granted bioRxiv a license to display the preprint in perpetuity. It is made available under aCC-BY-NC-ND 4.0 International license.

Entomologist's Monthly Magazine 86:171-178

Penick CA, Prager SS, Liebig J (2012) Juvenile hormone queen development in late-stage larvae of the ant Harpegnathos saltator Journal of Insect Physiology 58(12):1643-1649 doi:10.1016/j.jinsphys.2012.10.004

Pontieri L, Schmidt AM, Singh R, Pedersen JS, Linksvayer TA (2017) Artificial selection on ant female caste ratio uncovers a link between female-biased sex ratios and infection by Wolbachia endosymbionts Journal of Evolutionary Biology 30:225-234 doi:10.1111/jeb.13012

Powell S, Price SL, Kronauer DJC (2020) Trait evolution is reversible, repeatable, and decoupled in the soldier caste of the turtle ants Proceedings of the National Academy of Sciences 117(12):6608-6615 doi: https://doi.org/10.1073/pnas.1913750117

Qui B, Stenbak Larsen R, Chang N-C, Wang J, Boomsma JJ, Zhang G (2018) Towards reconstructing the ancestral brain gene-network regulating caste differentiation in ants Nature Ecology \& Evolution 2:1782-1791 doi:https://doi.org/10.1038/s41559-018-0689-x

Quiring R, Walldorf U, Kloter U, Gehring WJ (1994) Homology of the eyeless gene of Drosophila to the Small eye gene in mice and Aniridia in humans Science 265(5173):785-789 doi: 10.1126/science.7914031

Rafiqi AM, Lemke S, Ferguson S, Stauber M, Schmidt-Ott (2008) Evolutionary origin of the amnioserosa in cyclorrhaphan flies correlates with spatial and temporal expression changes of zen Proceedings of the National Academy of Sciences 105(1): 234-239 doi: 10.1073/pnas.0709145105

Rafiqi AM, Rajakumar A, Abouheif E (2020) Origin and elaboration of a major evolutionary transition in individuality Nature 585:239-244 doi: https://doi.org/10.1038/s41586-020-2653-6

Rajakumar R et al (2018) Social regulation of a rudimentary organ generates complex worker-caste systems in ants Nature 562:574-577 doi:https://doi.org/10.1038/s41586-018-0613-1

Rajakumar R et al (2012) Ancestral developmental potential facilitates parallel evolution in ants Science 335(6064):79-82 doi: 10.1126/science. 1211451

Sameshima S-Y, Miura T, Matsumoto T (2004) Wing disc development during caste differentiation in the ant Pheidole megacephala (Hymenoptera: Formicidae) Evolution \& Development 6(5): 336-341 doi:https://doi.org/10.1111/j.1525-142X.2004.04041.x

Sanger TJ, Rajakumar R (2018) How a growing organismal perspective is adding new depth to integrative studies of morphological evolution Biological Reviews 94:184-198 doi:https://doi.org/10.1111/brv.12442

Santos EM, Berger CS, Refki PN, Khila A (2015) Integrating evo-devo with ecology for a better understanding of phenotypic evolution Briefings in Functional Genomics 14(6):384-395 doi:https://doi.org/10.1093/bfgp/elv003

Schrader L et al. (2014) Transposable element islands facilitate adaptation to novel environments in an invasive species Nature Communications 5(5495) doi: https://doi.org/10.1038/ncomms6495

Schultner E, Oettler J, Helanterä H (2017) The Role of Brood in Eusocial Hymenoptera The Quarterly Review of Biology 92:39-78 doi:10.1086/690840

Simola DF et al. (2016) Epigenetic (re)programming of caste-specific behavior in the ant Camponotus floridanus Science 351(6268) doi:https://doi.org/10.1126/science.aac6633

Singh R, Linksvayer TA (2020) Wolbachia-infected ant colonies have increased reproductive investment and an accelerated life cycle Jounral of Experimental Biology223: jeb220079 doi: 10.1242/jeb.220079

Solis DR, Fox EGP, Kato LM, Jesus CMd, Yabuki AT, Campos AEdC, Bueno OC (2010) Morphological description of the immatures of the ant,Monomorium floricola J Insect Sci 10:15-15 doi:10.1673/031.010.1501

Sommer RJ, Mayer MG (2015) Toward a synthesis of developmental biology with evolutionary theory and ecology Annual Review of Cell and Developmental Biology 31(1):453-471

Tanquary MC (1912) Biological and Embryological Studies on Formicidae. PhD thesis University of Illinois Toth AL, Rehan SM (2017) Molecular evolution of insect sociality: an Eco-Evo-Devo persepctive Annual Review of Entomology 62:419-442 doi: https://doi.org/10.1186/s13227-015-0031-5

Tram U, Sullivan W (2000) Reciprocal inheritance of centrosomes in the parthenogenetic Hymenopteran Nasonia vitripennis Curr Biol 10:1413-1419 doi:https://doi.org/10.1016/S0960-9822(00)00795-8 
1004

1005

1006

1007

1008

1009

1010

1011

1012

1013

1014

1015

1016

1017

1018

1019

1020

1021

1022

1023

1024

1025

1026

1027

1028

1029

1030

1031

1032

1033

1034

1035

1036

1037

1038

1039

1040

1041

1042

1043

1044

1045

1046

1047

1048

1049

1050

1051

1052

1053

1054

1055

Trible W et al. (2017) orco Mutagenesis Causes Loss of Antennal Lobe Glomeruli and Impaired Social Behavior in Ants Cell 170:727-735.e710 doi:10.1016/j.cell.2017.07.001

Wagner G (2014) Homology, Genes, and Evolutionary Innovation Princeton; Oxford: Princeton University Press doi: doi:10.2307/j.ctt6wpzfz

Walsh JT, Warner MR, Kase A, Cushing BJ, Linksvayer TA (2018) Ant nurse workers exhibit behavioural and transcriptomic signatures of specialization on larval stage Anim Behav 141:161-169 doi:https://doi.org/10.1016/j.anbehav.2018.05.015

Walsh JT, Pontieri L, d'Ettorre P, Linksvayer TA (2020) Ant cuticular hydrocarbons are heritable and associated with variation in colony productivity Proceedings of the Royal Society Part B: Biological Sciences 287(1928) doi: https://doi.org/10.1098/rspb.2020.1029

Walsh JT, Garnier S, Linksvayer TA (2020) Ant collective behaviour is heritable and shaped by selection American Naturalist doi: https://doi.org/10.1086/710709

Warner MR, Kovaka K, Linksvayer TA (2016) Late-instar ant worker larvae play a prominent role in colony-level caste regulation Insect Soc:1-9 doi:10.1007/s00040-016-0501-3

Warner MR, Lipponen J, Linksvayer TA (2018) Pharaoh ant colonies dynamically regulate reproductive allocation based on colony demography Behav Ecol Sociobiol 72:31 doi:10.1007/s00265-017-24301

Warner MR, Mikheyev AS, Linksvayer TA (2019) Transcriptomic basis and evolution of the ant nurse-larval social interactome Plos Genet 15:e1008156 doi:10.1371/journal.pgen.1008156

Warner MR, Qui L, Holmes MJ, Mikheyev AS, Linksvayer T (2019) Covergent eusocial evolution is based on a shared reproductive groudplan plus lineage-specific plastic genes Nature Communications 10(2651) doi: https://doi.org/10.1038/s41467-019-10546-w

Wasik BR, Moczek AP (2012) pangolin expression influences the development of a morphological novelty: Beetle horns Genesis 50:404-414 doi:10.1002/dvg.20814

West-Eberhard MJ (2003) Developmental plasticity and evolution Oxford ; New York: Oxford University Press

Wheeler DE (1986) Developmental and physiological determinants of caste in social Hymenoptera evolutionary implications American Naturalist 128(1):13-34

Wheerler DE, Nijhout HF (1981) Imaginal wing discs in larvae of the soldier caste of Pheidole bicarinata vinelandica Florel (Hymenoptera: Formicidae) International Journal of Insect Morphology and Embryology 10(2):131-139 doi: https://doi.org/10.1016/S0020-7322(81)80018-9

Wheeler DE, Nijhout HF (2003) Soldier determination in Pheidole bicarinata: Effect of methoprene on caste and size within castes Journal of Insect Physiology 29(11):847-854 doi:https://doi.org/10.1016/00221910(83)90151-8

Wheeler GC, Wheeler J (1953) The Ant Larvae of the Subfamily Formicinae Ann Entomol Soc Am 46:126171 doi:10.1093/aesa/46.1.126

Wheeler GC, Wheeler J (1955) The Ant Larvae of the Myrmicine Tribe Solenopsidini The American Midland Naturalist 54:119-141 doi:10.2307/2422182

Wheeler GC, Wheeler J (1976) Ant larvae: review and synthesis. vol 7. Entomological Society of Washington Washington, DC,

Wheeler GC, Wheeler J (1990) Notes on ant larvae Transactions of the American Entomological Society 115:457-473

Wheeler WM (1893) A contribution to insect embryology Journal of Morphology 8(1):1-161 doi:https://doi.org/10.1002/jmor.1050080102

Wheeler WM (1910) Ants: Their Structure, Development and Behavior New York: The Columbia University Press

Wheeler WM (1911) The ant-colony as an organism Journal of Morphology 22:307-325 doi:doi:10.1002/jmor.1050220206

Wheeler WM (1918) A Study of Some Ant Larvae, with a Consideration of the Origin and Meaning of the Social Habit amoung Insects. Proceedings of the American Philosophical Society 57(4):293-343

Wheeler WM (1922) II. - The ants collected by the american museum congo expedition Bulletin of The American Museum of Natural History 45:39-269 
bioRxiv preprint doi: https://doi.org/10.1101/2020.12.22.423970; this version posted December $22,2020$. The copyright holder for this preprint (which was not certified by peer review) is the author/funder, who has granted bioRxiv a license to display the preprint in perpetuity. It is made available under aCC-BY-NC-ND 4.0 International license.

1056 Yan H et al. (2017) An Engineered orco Mutation Produces Aberrant Social Behavior and Defective Neural Development in Ants Cell 170:736-747.e739 doi:10.1016/j.cell.2017.06.051

Yang AS, Abouheif E (2011) Gynandromorphs as indicators of modularity and evolvability in ants Journal of Experimental Zoology Part B: Molecular and Developmental Evolution 316B(5):313-318 doi:https://doi.org/10.1002/jez.b.21407 
bioRxiv preprint doi: https://doi org/10.1101/2020.12 22 423970; this version posted December 22, 2020. The copyright holder for this preprint (which was not certified by peer review) is the author/funder, who has granted bioRxiv a license to display the preprint in perpetuity. It is made available under aCC-BY-NC-ND 4.0 International license.

1063

1064

Figure 1
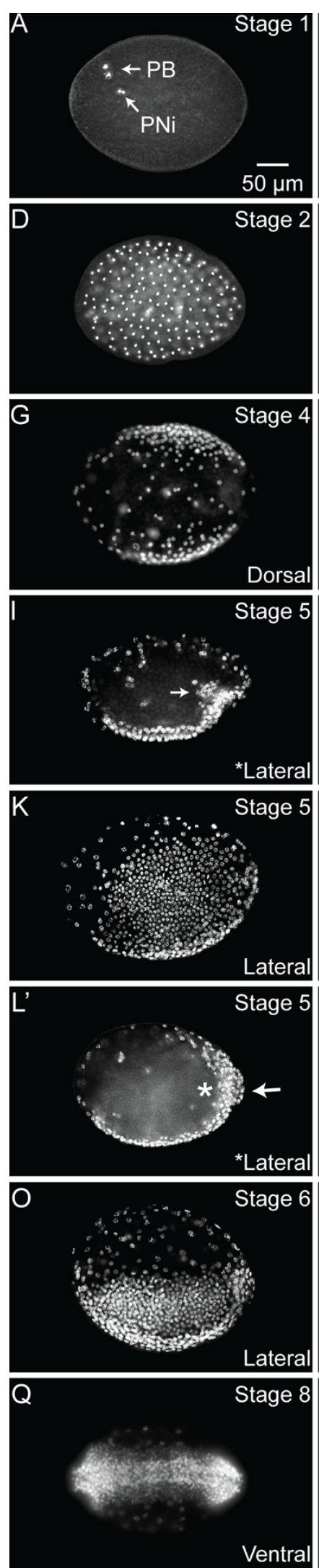
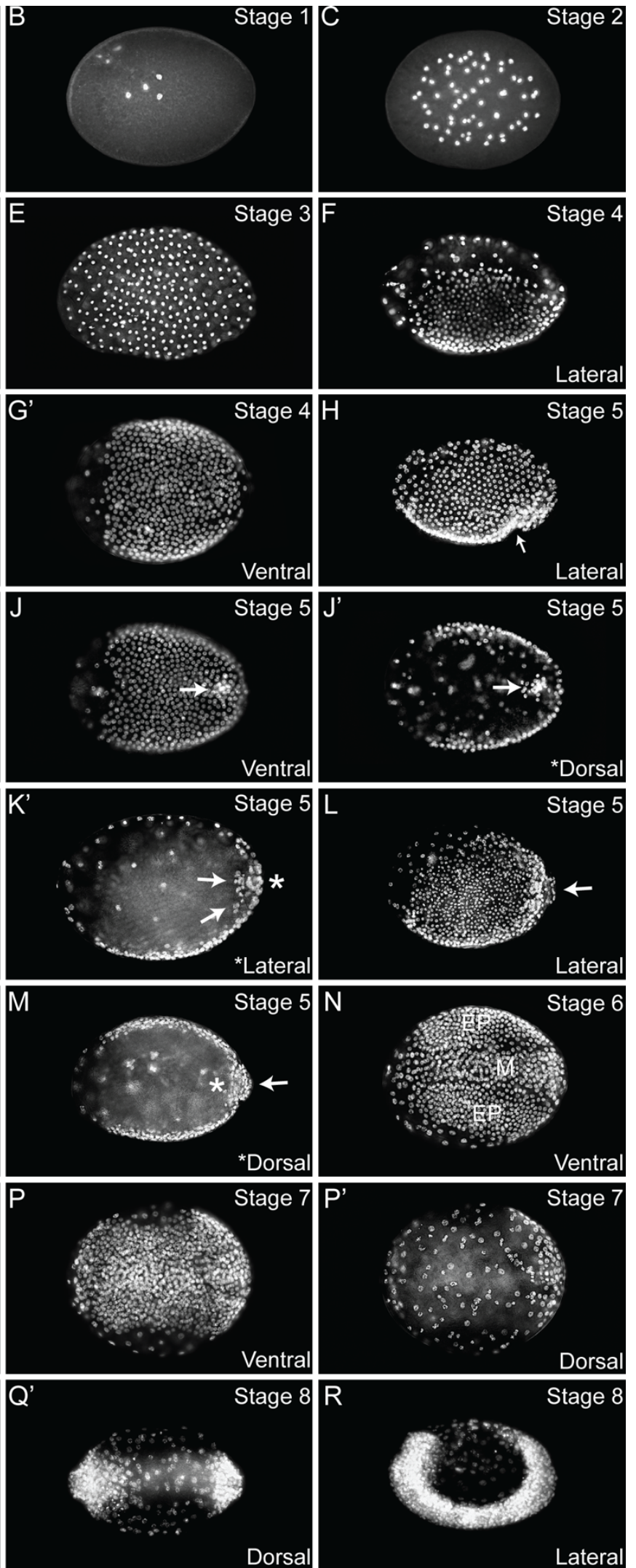
bioRxiv preprint doi: https://doi org/10.1101/2020.12 22 423970; this version posted December 22, 2020. The copyright holder for this preprint (which was not certified by peer review) is the author/funder, who has granted bioRxiv a license to display the preprint in perpetuity. It is made available under aCC-BY-NC-ND 4.0 International license.

1067

Figure 2

1068
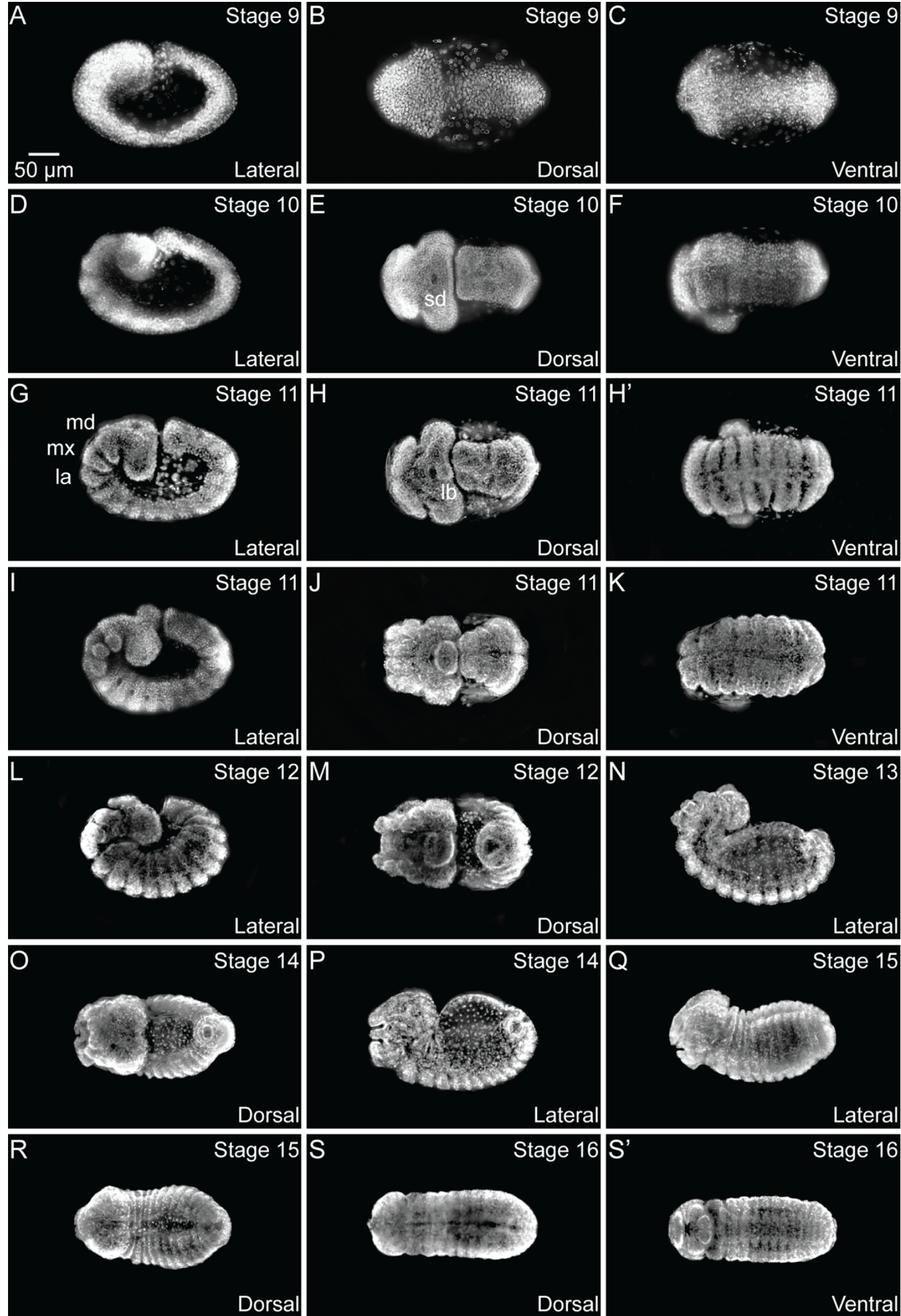
bioRxiv preprint doi: https://doi.org/10.1101/2020 1222 423970; this version posted December 22,2020 . The copyright holder for this preprint (which was not certified by peer review) is the author/funder, who has granted bioRxiv a license to display the preprint in perpetuity. It is made available under aCC-BY-NC-ND 4.0 International license.

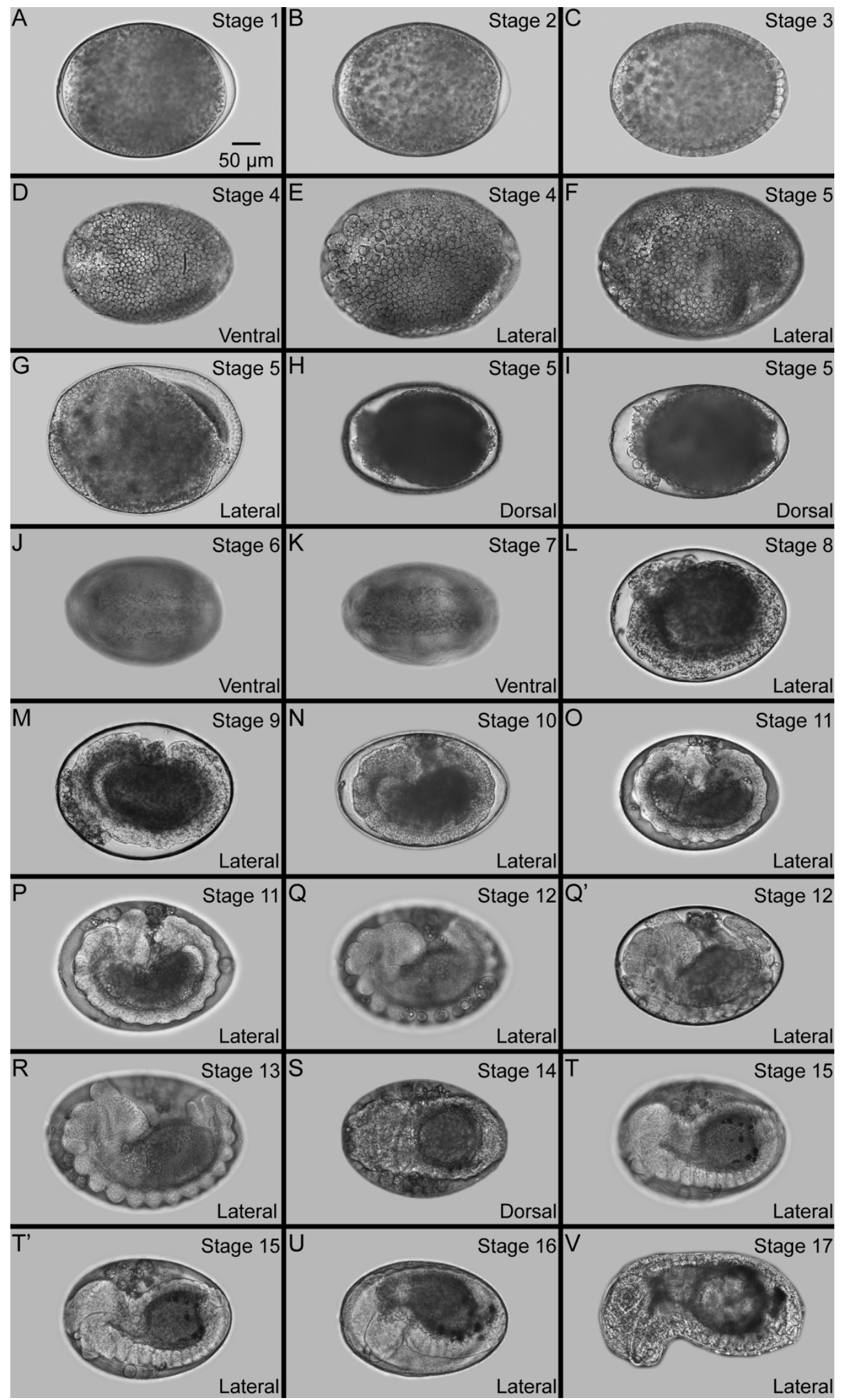


bioRxiv preprint doi: https://doi.org/10.1101/2020.12.22.423970; this version posted December 22, 2020. The copyright holder for this

preprint (which was not certified by peer review) is the author/funder, who has granted bioRxiv a license to display the preprint in perpetuity. It is made available under aCC-BY-NC-ND 4.0 International license.

\section{Figure 4}

1076 b $\left.\right|^{a}$

a

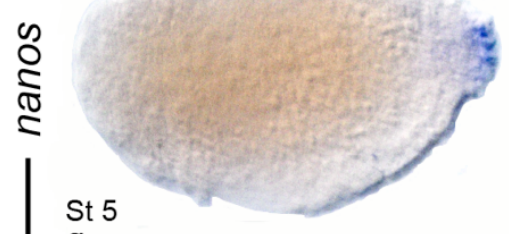

g

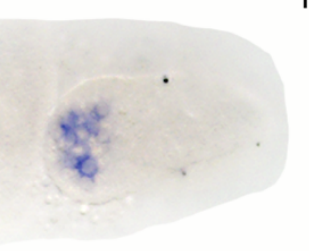

St 10 dorsal view

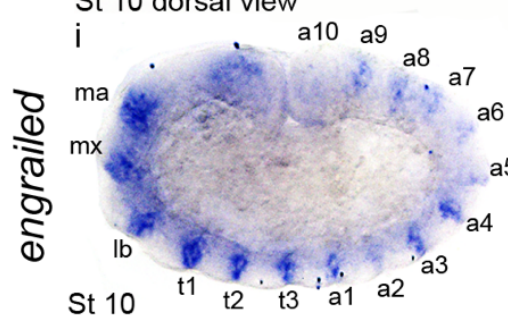

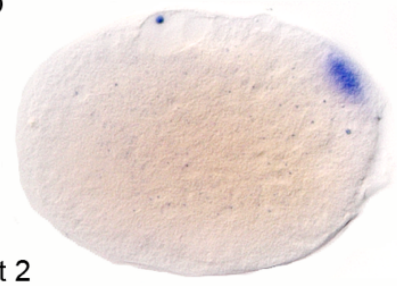

2

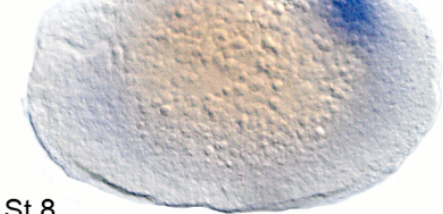

h

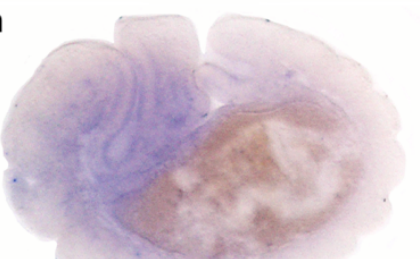

St 12

j $\mathrm{ma}$

mx

lb

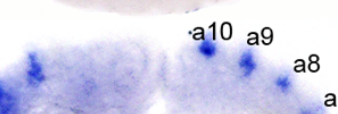

St 11

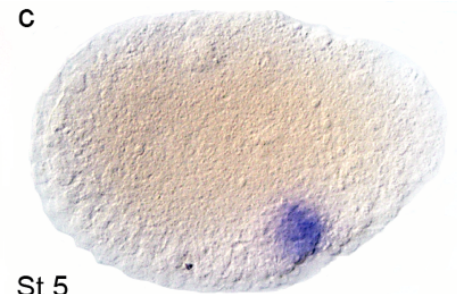

$\mathrm{f}$

St 10

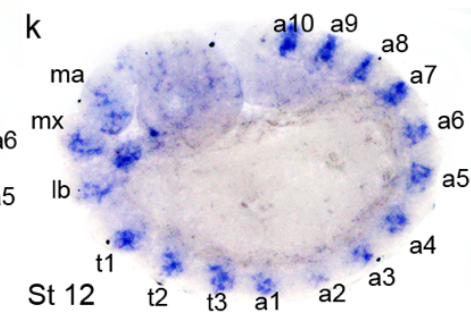


bioRxiv preprint doi: https://doi org/10.1101/2020.12.22.423970; this version posted December 22, 2020. The copyright holder for this preprint (which was not certified by peer review) is the author/funder, who has granted bioRxiv a license to display the preprint in perpetuity. It is made available under aCC-BY-NC-ND 4.0 International license.

1079 Figure 5

1080

A
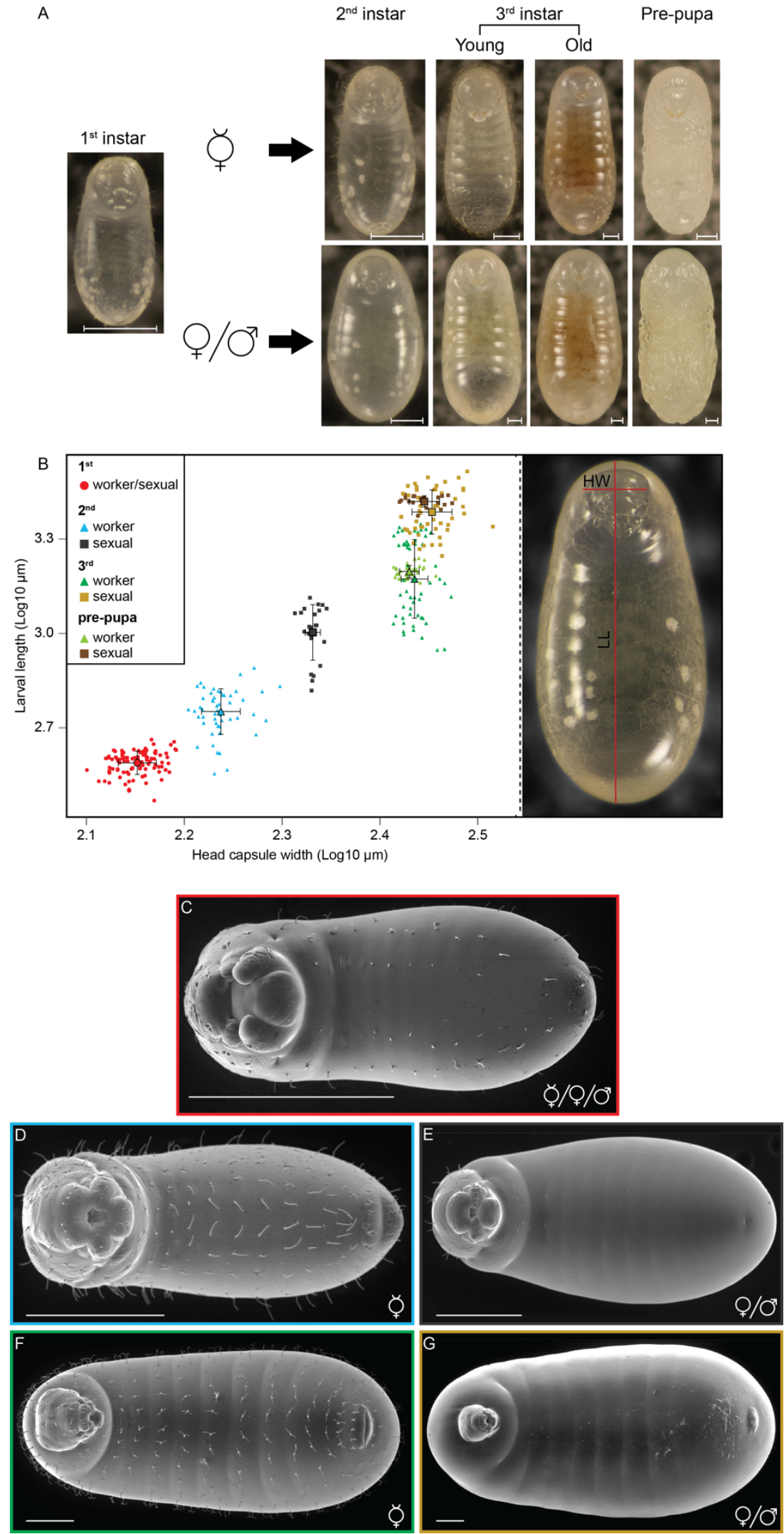
bioRxiv preprint doi: https://doi.org/10.1101/2020.12.22 423970; this version posted December 22, 2020. The copyright holder for this preprint (which was not certified by peer review) is the author/funder, who has granted bioRxiv a license to display the preprint in perpetuity. It is made available under aCC-BY-NC-ND 4.0 International license.
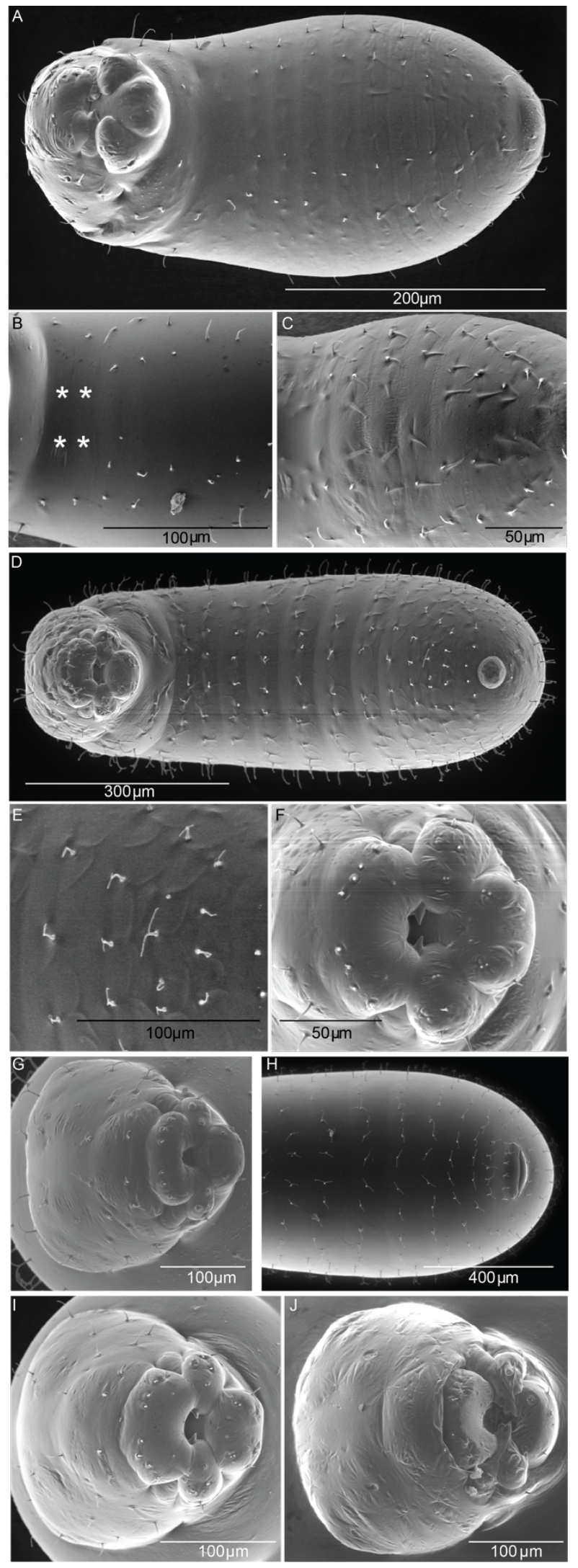
bioRxiv preprint doi: https://doi org/10.1101/2020.12.22.423970; this version posted December 22, 2020. The copyright holder for this preprint (which was not certified by peer review) is the author/funder, who has granted bioRxiv a license to display the preprint in perpetuity. It is made available under aCC-BY-NC-ND 4.0 International license.

1087

1088

\section{Figure 7}

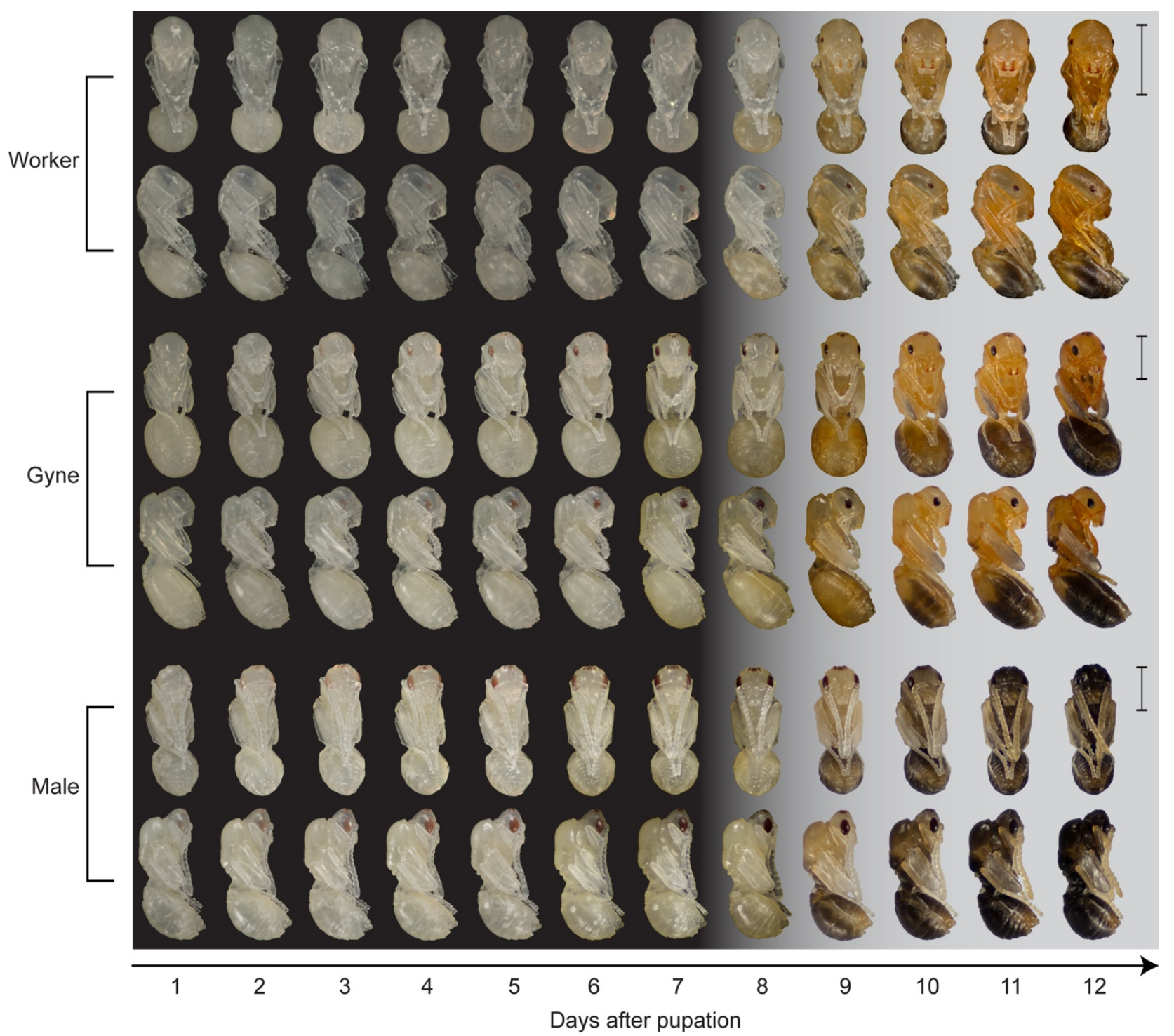


bioRxiv preprint doi: https://doi.org/10.1101/2020.12.22.423970; this version posted December 22, 2020. The copyright holder for this

preprint (which was not certified by peer review) is the author/funder, who has granted bioRxiv a license to display the preprint in perpetuity. It is made available under aCC-BY-NC-ND 4.0 International license.

1091

1092

\section{Figure 8}

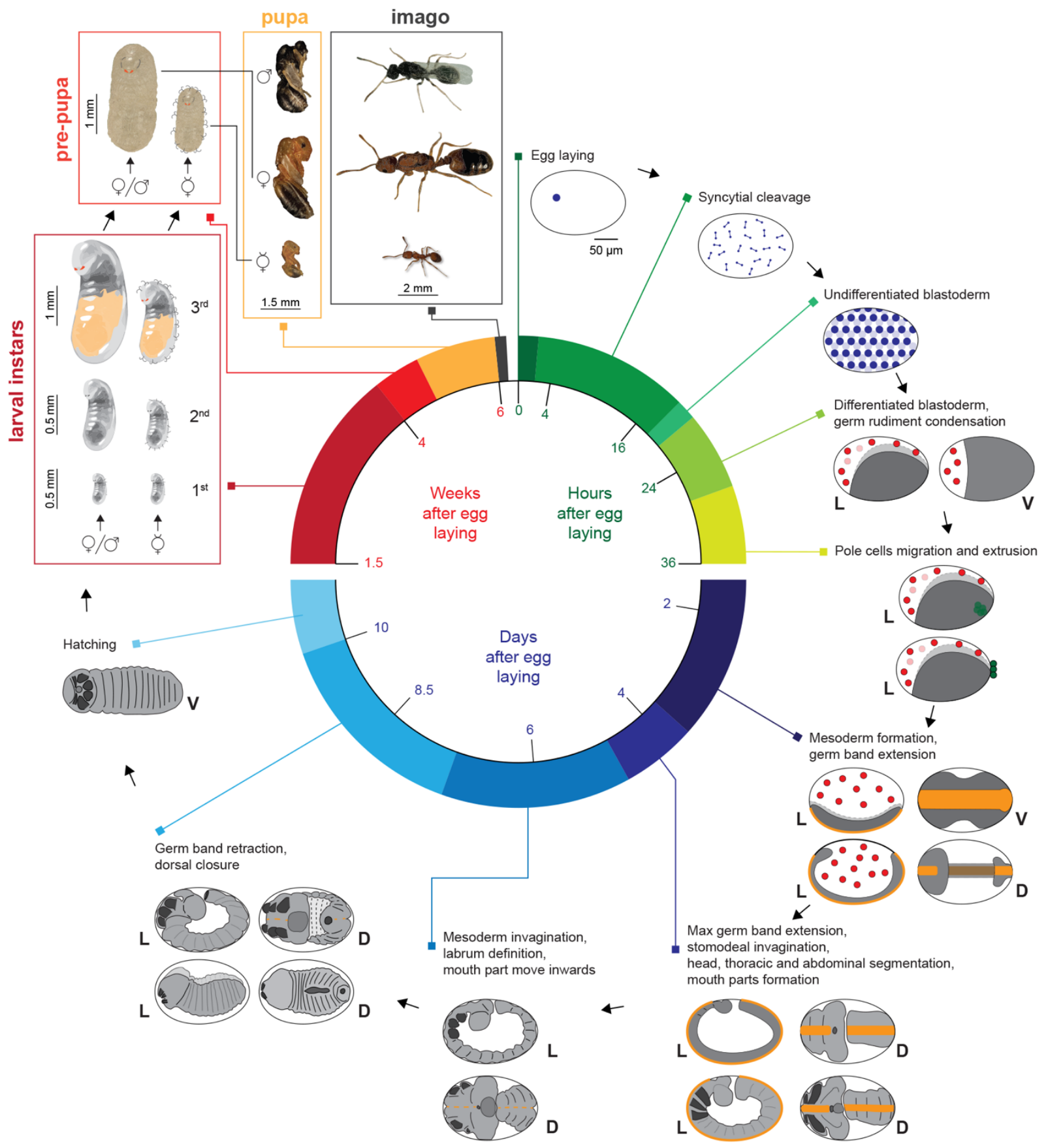

